\title{
Kidney-based in vitro models for drug-induced toxicity testing
}

\author{
João Faria ${ }^{1} \cdot$ Sabbir Ahmed $^{1} \cdot$ Karin G. F. Gerritsen $^{2} \cdot$ Silvia M. Mihaila $^{1,2} \cdot$ Rosalinde Masereeuw $^{1}$ (D)
}

Received: 30 July 2019 / Accepted: 15 October 2019 / Published online: 29 October 2019

(C) The Author(s) 2019

\begin{abstract}
The kidney is frequently involved in adverse effects caused by exposure to foreign compounds, including drugs. An early prediction of those effects is crucial for allowing novel, safe drugs entering the market. Yet, in current pharmacotherapy, drug-induced nephrotoxicity accounts for up to $25 \%$ of the reported serious adverse effects, of which one-third is attributed to antimicrobials use. Adverse drug effects can be due to direct toxicity, for instance as a result of kidney-specific determinants, or indirectly by, e.g., vascular effects or crystals deposition. Currently used in vitro assays do not adequately predict in vivo observed effects, predominantly due to an inadequate preservation of the organs' microenvironment in the models applied. The kidney is highly complex, composed of a filter unit and a tubular segment, together containing over 20 different cell types. The tubular epithelium is highly polarized, and the maintenance of this polarity is critical for optimal functioning and response to environmental signals. Cell polarity is dependent on communication between cells, which includes paracrine and autocrine signals, as well as biomechanic and chemotactic processes. These processes all influence kidney cell proliferation, migration, and differentiation. For drug disposition studies, this microenvironment is essential for prediction of toxic responses. This review provides an overview of drug-induced injuries to the kidney, details on relevant and translational biomarkers, and advances in 3D cultures of human renal cells, including organoids and kidney-on-a-chip platforms.
\end{abstract}

Keywords Nephrotoxicity $\cdot$ Drug-induced kidney injury $\cdot$ In vitro models $\cdot$ Biomarkers

\begin{tabular}{|c|c|c|c|}
\hline \multicolumn{2}{|c|}{ Abbreviations } & B2 M & Beta-2 microglobulin \\
\hline \multirow{3}{*}{$\begin{array}{l}\text { L-DOPA } \\
\text { ADME }\end{array}$} & 3,4-Dihydroxyl-L-phenylalanine & BUN & Blood urea nitrogen \\
\hline & Absorption, distribution, metabolism, and & BCRP & Breast cancer resistance protein \\
\hline & excretion & CRS & Cardiorenal syndrome \\
\hline AIN & Acute interstitial nephritis & CKD & Chronic kidney disease \\
\hline AKI & Acute kidney injury & CLU & Clusterin \\
\hline ATN & Acute tubular necrosis & CIHP & Conditionally immortalized human podocyte \\
\hline \multirow{2}{*}{$\begin{array}{l}\text { ASC } \\
\text { ALP }\end{array}$} & Adult stem cell & ciPTEC & Conditionally immortalized proximal tubule \\
\hline & Alkaline phosphatase & & epithelial cell \\
\hline $\mathrm{ARB}$ & Angiotensin receptor blocker & CysC & Cystatin $\mathrm{C}$ \\
\hline ACEI & Angiotensin-converting enzyme inhibitors & CYP & Cytochrome P450 \\
\hline $\mathrm{ABC}$ & ATP-binding cassette & ESKD & End-stage kidney disease \\
\hline \multirow{2}{*}{\multicolumn{2}{|c|}{ Autosomal dominant polycystic kidn }} & EMA & European Medicines Agency \\
\hline & & $\mathrm{ECM}$ & Extracellular matrix \\
\hline \multicolumn{2}{|c|}{ João Faria and Sabbir Ahmed have contributed equally. } & & Food and Drug Administration \\
\hline \multirow{2}{*}{\multicolumn{2}{|c|}{$\begin{array}{l}\text { Rosalinde Masereeuw } \\
\text { r.masereeuw@uu.nl }\end{array}$}} & G $\gamma_{-} \mathrm{GT}$ & pyl transnentidase transterase \\
\hline & & 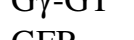 & $\gamma$-Giutamyi transpeptidase transierase \\
\hline \multirow{5}{*}{\multicolumn{2}{|c|}{$\begin{array}{l}\text { Division of Pharmacology, Department of Pharmaceutical } \\
\text { Sciences, Utrecht Institute for Pharmaceutical Sciences, } \\
\text { Utrecht University, Universiteitsweg 99, } 3584 \text { CG Utrecht, } \\
\text { The Netherlands }\end{array}$}} & पEC & Clor \\
\hline & & & fascuial \\
\hline & & IS & ansferase \\
\hline & & $\mathrm{HO}$ & Heme oxygenase \\
\hline & & HUS & Hemolytic-uremic syndrome \\
\hline \multicolumn{2}{|c|}{ Department of Nephrology and Hypertension, University } & HRS & Hepatorenal syndrome \\
\hline
\end{tabular}




$\begin{array}{ll}\text { HFM } & \text { Hollow fiber membrane } \\ \text { hTERT } & \text { Human telomerase reverse transcriptase } \\ \text { IVIVE } & \text { In vitro-to-in vivo extrapolation } \\ \text { iPSC } & \text { Induced pluripotent stem cell } \\ \text { IGFBP } & \text { Insulin-like growth factor-binding protein } \\ \text { IVIG } & \text { Intravenous immunoglobulin } \\ \text { IRI } & \text { Ischemia-reperfusion injury } \\ \text { KIM } & \text { Kidney injury molecule } \\ \text { L-FABP } & \text { Liver type-fatty acid binding protein } \\ \text { MMP } & \text { Matrix metalloproteinase } \\ \text { MTX } & \text { Methotrexate } \\ \text { MEM } & \text { Microelectromechanical systems } \\ \text { MPS } & \text { Microphysiological systems } \\ \text { MCP } & \text { Monocyte chemotactic protein } \\ \text { MATE } & \text { Multidrug and toxin extrusion protein } \\ \text { MRP } & \text { Multidrug resistance protein } \\ \text { NAG } & \text { N-Acetyl- } \beta \text {-glucosaminidase } \\ \text { NGAL } & \text { Neutrophil gelatinase-associated lipocalin } \\ \text { NSAIDs } & \text { Nonsteroidal anti-inflammatory drugs } \\ \text { OAT } & \text { Organic anion transporters } \\ \text { OCT } & \text { Organic cation transporter } \\ \text { OPN } & \text { Osteopontin } \\ \text { P-gp } & \text { P-glycoprotein } \\ \text { PBPK } & \text { Physiologically based pharmacokinetic } \\ \text { PES } & \text { Polyethersulfone } \\ \text { PSTC } & \text { Predictive Safety Testing Consortium } \\ \text { RPA } & \text { Renal papillary antigen } \\ \text { RPTEC } & \text { Renal proximal tubule epithelial cell } \\ \text { RAS } & \text { Renin-angiotensin system } \\ \text { RBP } & \text { Retinol binding protein } \\ \text { sCr } & \text { Serum creatinine } \\ \text { SV40T } & \text { Simian virus 40 large T antigen } \\ \text { SDS } & \text { Sodium dodecyl sulfate } \\ \text { SLC } & \text { Solute carrier family } \\ \text { 3D } & \text { Three-dimensional } \\ \text { TIMP } & \text { Tissue inhibitor of metalloproteinase } \\ \text { TEER } & \text { Transepithelial electrical resistance } \\ \text { TFF } & \text { Trefoil factor } \\ \text { 2D } & \text { Two-dimensional } \\ \text { uALB } & \text { Urinary albumin } \\ \text { uTP } & \text { Urinary total protein } \\ & \end{array}$

\section{Introduction}

The kidneys play an essential role in preserving homeostasis of the body's internal environment, including regulation of water, electrolyte, nitrogen, and acid-base balances. They also control the red blood cell production and blood pressure (Bello-Reuss and Reuss 1983). Impaired renal function is commonly observed in clinical practice and is often associated with the use of drugs. One-third of all drugs and drug candidates are excreted unchanged from the body by the kidneys, and drug-induced nephrotoxicity accounts for $20 \%$ of all episodes that lead to acute kidney failure (Naughton 2008b).

Human kidneys contain around 1 million nephrons. A nephron is composed of different subunits and includes the glomerulus, proximal tubule, loop of Henle, distal tubule, and the collecting duct (Lote 2012) (Fig. 1). All subunits contribute to the excretory function of the kidney in three steps: glomerular filtration, tubular reabsorption, and tubular secretion (Koeppen and Stanton 2013). During glomerular filtration (Fig. 2), blood plasma is filtered in the glomerulus, a bundle of porous capillaries lined by a membrane and specialized epithelial cells, that allows solutes and waste, including drugs and their metabolites, and water to pass through while ensuring larger substances, such as blood cells and proteins, remain in the circulatory system (Holechek 2003). Protein-bound molecules, including drugs, are eliminated by proximal tubular secretion via a well-coordinated process of uptake by the tubular cells at the blood-facing basolateral site and secretion into the tubular lumen. Tubular reabsorption begins as soon as the filtrate enters the lumen of the proximal tubule, and involves the reabsorption of organic nutrients, such as glucose, and hormonal-regulated reabsorption of ions coupled with passive water reabsorption. Megalin and cubilin receptors at the apical membrane are responsible for endocytosis-mediated reuptake of filtered low-molecular-weight proteins, such as $\beta 2$-microglobulin (Eshbach and Weisz 2017). As the filtrate travels along the nephron, some drugs, hydrogen ions, and ammonia are secreted into the collecting tubule (Feher 2017).

Even though the main function of the kidney is to excrete waste products from the bloodstream, it is important to mention that the kidney is also a major endocrine organ. Five very important hormones/enzymes are produced by the kidney, viz, 1,25-dihydroxyvitamin D3, erythropoietin, renin, Klotho, and kallikrein (Haussler et al. 2016); (Shimamoto and Iimura 1989). Calcitriol, 1,25-dihydroxyvitamin D3, is activated in the proximal tubule and acts in the reabsorption of calcium, but it is also involved in bone health and in the regulation of parathyroid function (Kumar et al. 2012). Erythropoietin is produced by peritubular capillary endothelial cells in the proximal tubule, and acts by stimulating the production of red blood cells in the bone marrow (Ohana et al. 2013). Renin is secreted by granular cells of the juxtaglomerular apparatus. This enzyme also known as angiotensinogenase is the key factor of the renin-angiotensin system (RAS) that leads to the production of the potent vasoconstrictor angiotensin controlling blood pressure (Lopez and Gomez 2010). Klotho is synthesized and secreted by the distal tubule. Similar to calcitriol, Klotho is involved in the calcium and phosphate homeostasis (Kim et al. 2015). Kallikrein of the renal kallikrein-kinin system is found in 


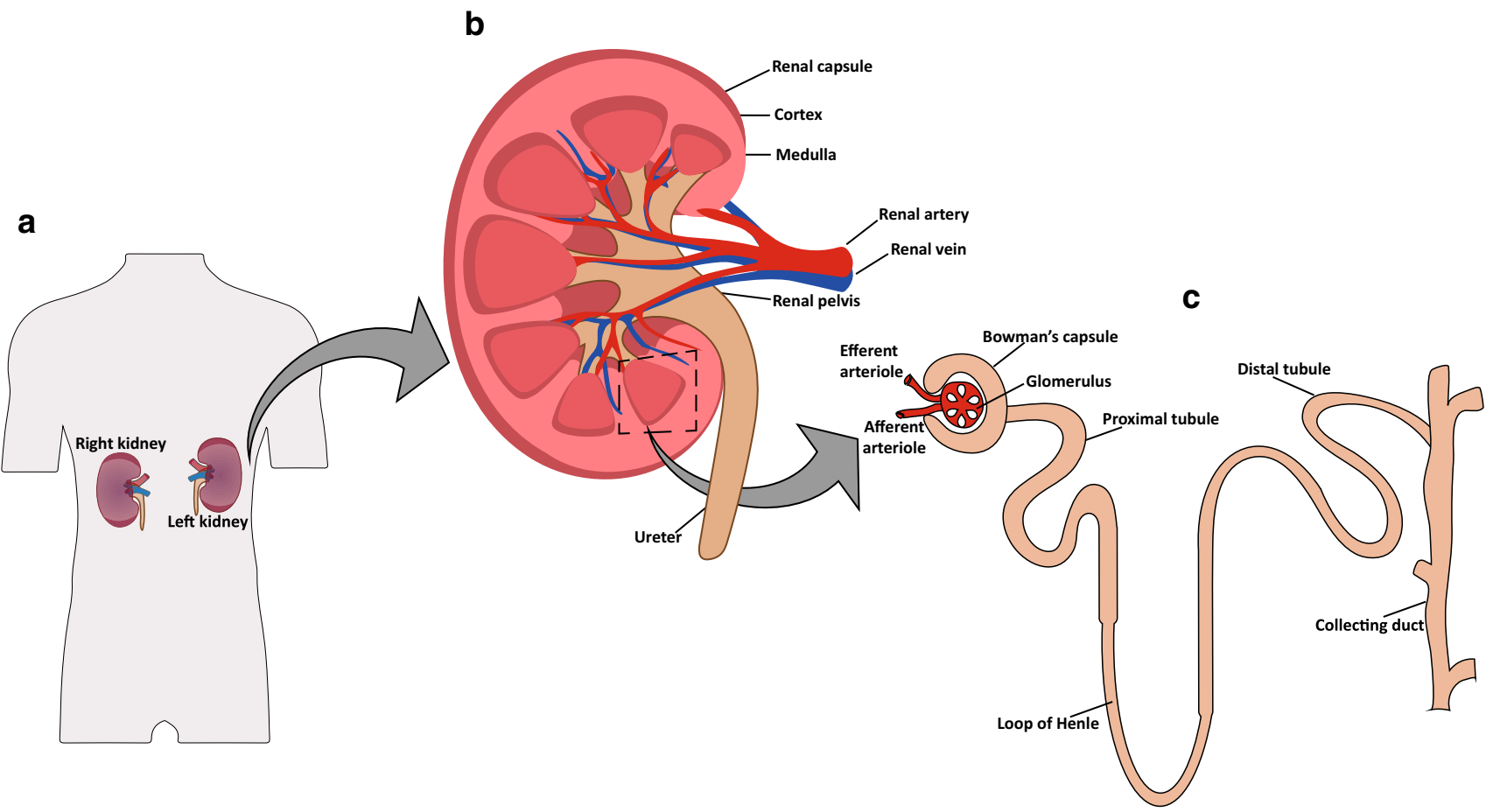

Fig. 1 Human kidney anatomy. External view (a), internal view (b), and its functional unit nephron (c)

the distal tubule, and is involved in the regulation of blood pressure (Kakoki and Smithies 2009).

Due to the complexity of the kidney, as an organ containing specialized structures and multiple cell types, it becomes quite difficult to find a reliable model system to study the effects or toxicity of drugs and their metabolites on this organ. In this review, detailed information on drug-induced kidney injury mechanisms and available in vitro models to predict this with relevant translational biomarkers will be discussed, with an emphasis on novel developments in the field of microphysiological systems that meet the requirements of the 3Rs (replacement, reduction, refinement) of animal experiments for drug safety screenings.

\section{Drug-induced kidney injury}

Exposure to various drugs or drug candidates for therapeutic or diagnostic purposes (Fig. 3) could possibly lead to toxicity in the kidney, resulting in damage of the tubules, interstitium, glomerulus, or renal microvasculature, and consequently resulting in various clinical manifestations (Table 1) (Małyszko et al. 2016). About 36\% of nephrotoxicity incidence has been attributed to antimicrobials (e.g., aminoglycosides). While in most cases, the drug-induced kidney injury is reversible upon cease of treatment some medications could lead to chronic dysfunction such as papillary necrosis, tubulointerstitial nephritis, or prolonged proteinuria (Choudhury and Ahmed 2006). Nephrotoxicity of most drugs is more severe in patients already suffering from kidney disease (Vervaet et al. 2017).

\section{Kidneys can experience both structural damage and loss of function}

Acute kidney injury (AKI) is characterized by an increase in blood levels of waste solutes, such as urea and creatinine, and often oliguria and electrolyte disorders. AKI can be classified into three categories: prerenal, intrinsic, and postrenal (Makris and Spanou 2016). In prerenal AKI, the kidney may function normally, but there is a decrease in either intravascular volume or arterial pressure, which results in a reduced glomerular filtration rate (GFR) (Macedo and Mehta 2009). RAS inhibitors such as angiotensin-converting enzyme inhibitors and angiotensin receptor blockers can also lead to prerenal AKI, as it causes dilation of the efferent arteriole which contributes to reduced intraglomerular pressure (Navis et al. 1996). Furthermore, nonsteroidal anti-inflammatory drugs (NSAIDs) are known to decrease the GFR by changing the balance of vasodilatory/vasoconstrictive agents in the renal microcirculation (Dixit et al. 2010). The most common type of intrinsic AKI is acute tubular necrosis, which is usually caused by ischemia or toxic injury (Basile et al. 2012). Postrenal AKI occurs when there is an obstruction of urinary flow that can lead to impaired renal blood 


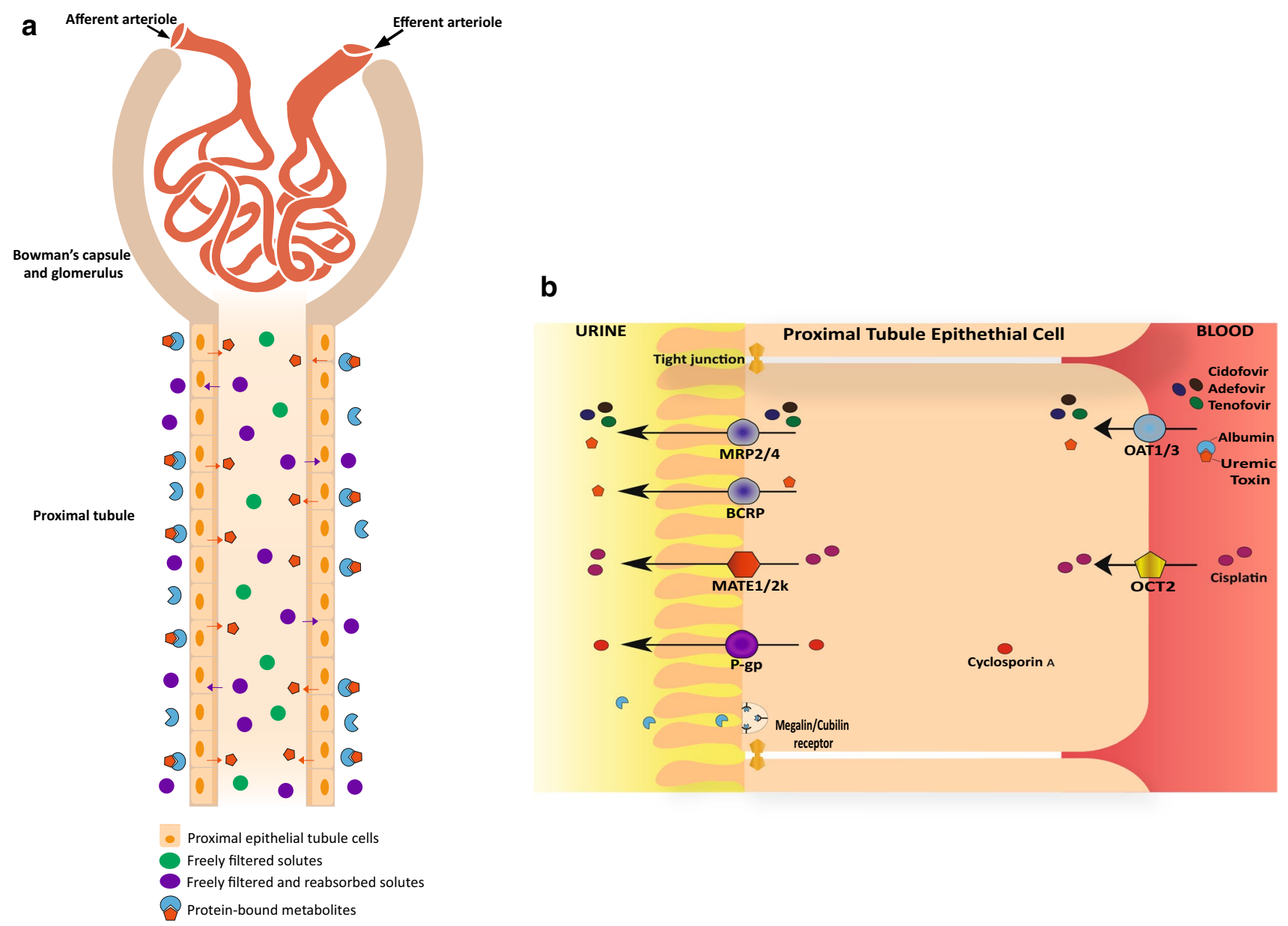

Fig. 2 The renal proximal tubule. a Blood plasma solutes and proteins pass through the glomerular filter. Organic and inorganic solutes (in green) are freely filtered by the glomerulus. Some solutes, such as glucose and amino acids (in purple), are reabsorbed completely by the proximal tubule epithelial cells and transferred back to the systemic circulation. Protein-bound metabolites (in orange) are actively secreted by the proximal tubule epithelial cells. b Drug transporters involved in nephrotoxicity. The organic anion transporters OAT1 $(S L C 22 A 6)$ and OAT3 $(S L C 22 A 8)$ are involved in the uptake of

flow and inflammatory processes, seen for example in urate and oxalate imbalances (Makris and Spanou 2016).

When these changes become persistent both in structure and function, AKI may progress to chronic kidney disease (CKD), and when not properly treated, it can lead to endstage kidney disease. The GFR is used to categorize CKD in five distinct stages, along with the presence or absence of proteinuria (Kipp and Kellerman 2009).

Nephrotoxicants, including chemotherapeutics, drugs of abuse, antimicrobials, radiocontrast agents, environmental pollutants, and natural substances, can induce kidney injury via similar mechanisms. Renal cell death can be mediated by drug transporters that determine the selectivity for the tubular cell, mitochondrial damage, and drug metabolism known antiviral agents, such as cidofovir, adefovir, and tenofovir, which will then be secreted by MRP2 (ABCC2) and MRP4 (ABCC4) located at the apical side of the membrane. The chemotherapeutic agent cisplatin is imported by OCT2 (SLC22A2) and exported via MATE1 (SLC47A1) and MATE2-k (SLC47A2). P-gp (ABCB1) is involved in the secretion of the immunosuppressant cyclosporin A. Uremic toxins, such as Indoxyl sulfate and kynurenic acid, are uptaken via OAT1 and excreted by MRP2/4 and BCRP (ABCG2) (color figure online)

(Barnett and Cummings 2018). The reabsorption of solutes by the kidneys is a task that demands a large consumption of energy. The proximal tubule is the nephron's segment that is the most susceptible to toxic effects due to its role in absorption and secretion, both requiring high rates of oxidative metabolism. For this reason, mitochondrial damage will lead to a reduction in ATP production that in turn will increase oxidative stress, disrupt cell volume, ion concentrations, and apoptosis or, in severe cases necrosis, thus compromising renal function (Eirin et al. 2017). Renal transporters may facilitate drugs to enter the tubular cells, sometimes followed by metabolism leading to their bioactivation (Liang et al. 2015a). These transporters belong to two large families: the solute carrier family (SLC) and the 
Fig. 3 Risk of drugs to affect kidney function. a The human body is subjected to a variety of nephrotoxicants, including chemotherapeutics, drugs of abuse, antimicrobials, environmental pollutants, and natural substances, which can induce kidney injury via several mechanisms. b These nephrotoxicants can lead to acute kidney injury (AKI). AKI is characterized by gradual loss of kidney function that, when not properly treated, can lead to irreversible kidney failure. Renal vasoconstriction, intrarenal factors, and obstruction are some of the effects of the nephrotoxicants on the kidney, which will lead to a decrease in the glomerular filtration rate (GFR). An estimation of the GFR is widely used in clinic as an indicator of kidney function

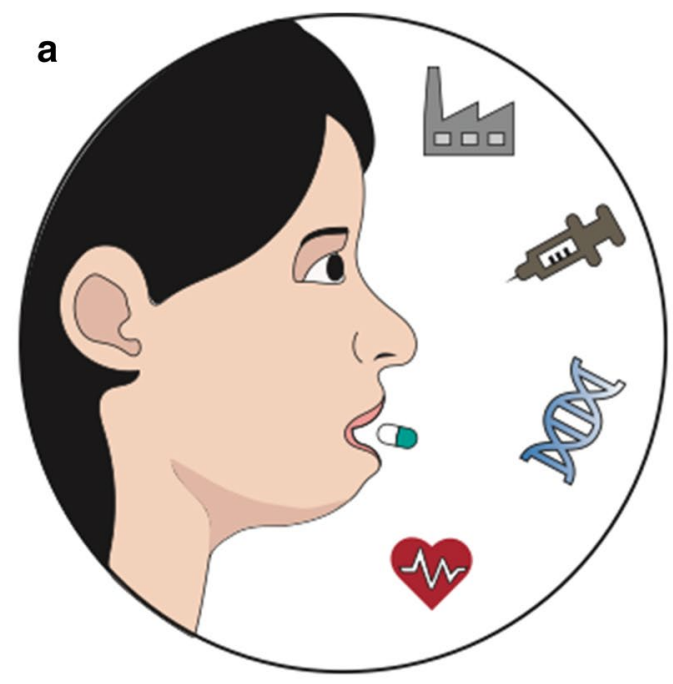

b

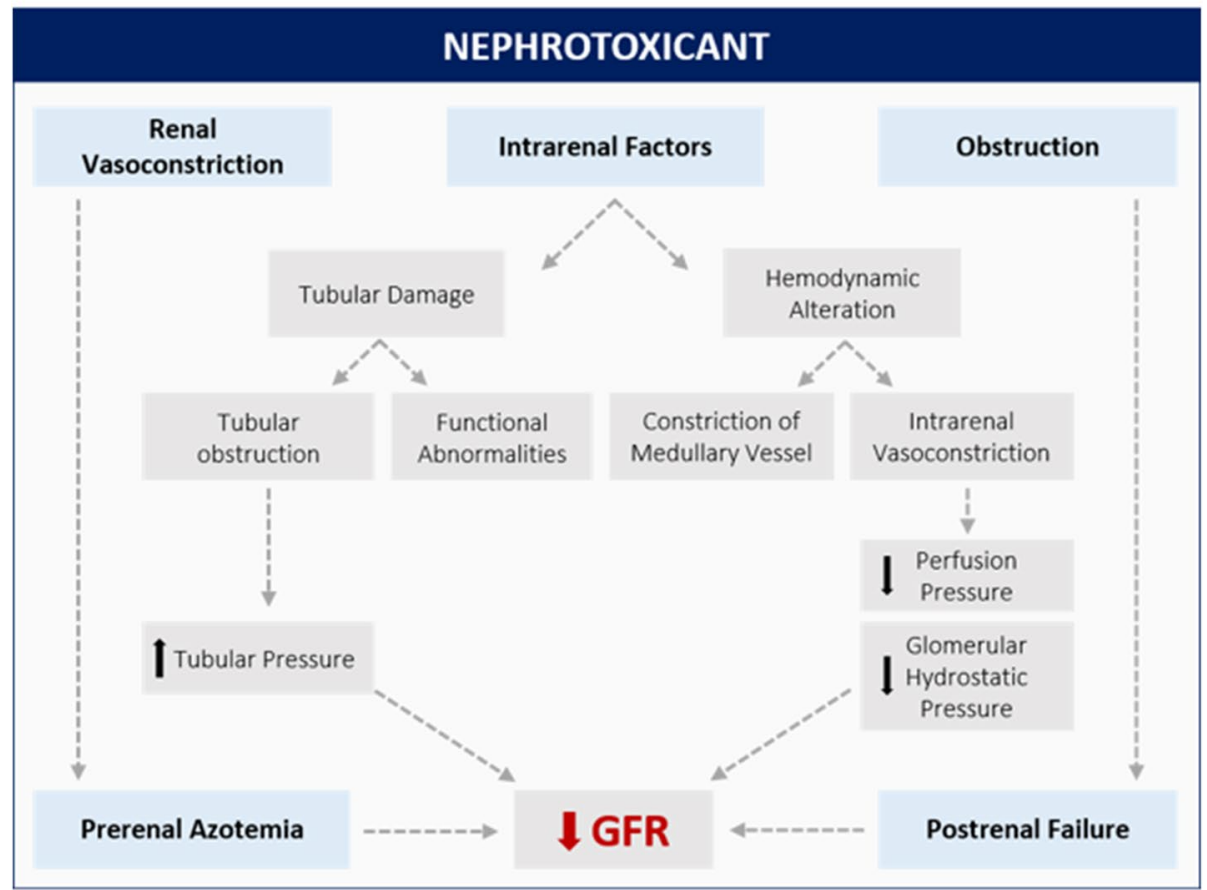

adenosine triphosphate (ATP)-binding cassette (ABC) transporter family. Uptake of organic anions (Fig. 2) is mediated by the organic anion transporters 1 (OAT1; SLC22A6) and 3 (OAT3; SLC22A8) and their removal from the cell via breast cancer resistance protein (BCRP; $A B C G 2)$, multidrug resistance protein 2 (MRP2; $A B C C 2)$ and 4 (MRP4; $A B C C 4$ ) (Giacomini et al. 2010; Nigam 2018; Nigam et al. 2015). Organic cations (Fig. 2) are transported into tubular cells predominantly via the basolateral organic cation transporter 2 (OCT2; SLC22A2) and then excreted into the tubular lumen via multidrug and toxin extrusion protein 1 (MATE1; SLC47A1) and 2-k (MATE2-k; SLC47A2) and P-glycoprotein (P-gp; $A B C B 1)$. Although most drugs are metabolized by the liver, some nephrotoxicants are known to be dependent on kidney metabolism as this organ also expresses Phase I (CYPs) and Phase II (GSTs) enzymes (Anders 1980).

\section{Vascular injury}

Several immunosuppressive agents such as cyclosporin, tacrolimus, and muromonab-CD3 may cause renal vascular injury by damaging primary endothelium that induces platelet aggregation and consumption. Such an effect is also associated with antiplatelet agents, for instance, ticlopidine and clopidogrel, and chemotherapeutic agents (e.g., mitomycin 
Table 1 Commonly used nephrotoxic drugs and associated toxicities

\begin{tabular}{|c|c|c|c|}
\hline Therapeutic class & Drugs & Toxic events & References \\
\hline Anticoagulants & Warfarin, heparin & $\begin{array}{l}\text { Renal tissue ischemia } \\
\text { Necrosis } \\
\text { Infarction }\end{array}$ & Brodsky (2014) \\
\hline Anticonvulsant & Phenytoin & $\begin{array}{l}\text { Acute interstitial Nephritis } \\
\text { Diabetes insipidus }\end{array}$ & Ghane Shahrbaf and Assadi (2015) \\
\hline \multirow[t]{2}{*}{ Antidepressant } & Amitriptyline & Rhabdomyolysis & Coco and Klasner (2004) \\
\hline & Lithium & $\begin{array}{l}\text { Chronic interstitial Nephritis } \\
\text { Glomerulonephritis } \\
\text { Rhabdomyolysis }\end{array}$ & $\begin{array}{l}\text { Azab et al. (2015) and Coco and Klas- } \\
\text { ner (2004) }\end{array}$ \\
\hline Antifungal agent & Amphotericin B & $\begin{array}{l}\text { ATN } \\
\text { Renal tubular acidosis (RTA) } \\
\text { Electrolyte imbalance } \\
\text { Urinary concentration Defects }\end{array}$ & Deray (2002) \\
\hline Antihistamine & Diphenhydramine, doxylamine & Rhabdomyolysis & Coco and Klasner (2004) \\
\hline \multirow[t]{2}{*}{ Antihypertensive } & Hydralazine, minoxidil & Prerenal azotemia & Ejaz et al. (2004) \\
\hline & $\begin{array}{l}\text { Angiotensin-converting enzyme } \\
\text { inhibitors, angiotensin II receptor } \\
\text { blockers }\end{array}$ & $\begin{array}{l}\text { Renal artery stenosis } \\
\text { Volume depletion }\end{array}$ & Palmer (2002) \\
\hline \multirow[t]{5}{*}{ Antimicrobials } & Aminoglycosides & $\begin{array}{l}\text { Hypomagnesemia } \\
\text { nonoliguric ATN } \\
\text { Chronic tubulointerstitial nephritis } \\
\text { Fanconi syndrome }\end{array}$ & Lopez-Novoa et al. (2011) \\
\hline & Vancomycin & $\begin{array}{l}\text { Acute tubular necrosis } \\
\text { Tubular damage }\end{array}$ & Htike et al. (2012) and Liu et al. (2015) \\
\hline & Ciprofloxacin & $\begin{array}{l}\text { AIN } \\
\text { Crystalluria }\end{array}$ & Bird et al. (2013) \\
\hline & Penicillin & Glomerulonephritis & Naughton (2008a) \\
\hline & Cephalosporin & Acute interstitial nephritis & Naughton (2008a) \\
\hline Antiplatelet & Ticlopidine, clopidogrel and quinine & $\begin{array}{l}\text { Thrombotic microangiopathy } \\
\text { Renal vascular injury }\end{array}$ & Medina et al. (2001) \\
\hline \multirow[t]{4}{*}{ Antiretroviral agents } & Cidofovir, adefovir & Proximal tubule damage & Kalyesubula and Perazella (2011) \\
\hline & Tenofovir & $\begin{array}{l}\text { ATN } \\
\text { Proximal tubulopathy }\end{array}$ & $\begin{array}{l}\text { Fernandez-Fernandez et al. (2011) and } \\
\text { Jafari et al. (2014) }\end{array}$ \\
\hline & Indinavir & $\begin{array}{l}\text { Tubular crystallization } \\
\text { Nephrolithiasis }\end{array}$ & Kalyesubula and Perazella (2011) \\
\hline & Atazanavir & AIN & Hara et al. (2015) \\
\hline \multirow[t]{3}{*}{ Antiviral } & Valaciclovir & $\begin{array}{l}\text { Thrombotic microangiopathy } \\
\text { Renal vascular injury }\end{array}$ & Izzedine et al. (2005) \\
\hline & Acyclovir & Tubular crystallization & Yildiz et al. (2013) \\
\hline & Foscarnet & $\begin{array}{l}\text { Crystal deposition } \\
\text { Electrolyte abnormalities }\end{array}$ & Frochot et al. (2016) \\
\hline Bisphosphonates & Bisphosphonate zoledronate & $\begin{array}{l}\text { Deranged Na-K-ATPase } \\
\text { Loss of brush border } \\
\text { Apoptosis }\end{array}$ & Markowitz et al. (2003) \\
\hline Calcineurin inhibitor & Rapamycin & $\begin{array}{l}\text { Tubular collapse } \\
\text { Vacuolization } \\
\text { Nephrocalcinosis }\end{array}$ & Marti and Frey (2005) \\
\hline
\end{tabular}


Table 1 (continued)

\begin{tabular}{|c|c|c|c|}
\hline Therapeutic class & Drugs & Toxic events & References \\
\hline \multirow[t]{6}{*}{ Chemotherapeutic agent } & Cisplatin & $\begin{array}{l}\text { Proximal tubular necrosis } \\
\text { Tubular cell deletion }\end{array}$ & Miller et al. (2010) \\
\hline & Nedaplatin & $\begin{array}{l}\text { Lysosomal hyperplasia } \\
\text { Necrosis and hyperplasia of renal } \\
\text { papilla and collecting duct }\end{array}$ & Uehara et al. (2011) \\
\hline & Mitomycin C & $\begin{array}{l}\text { Thrombotic microangiopathy } \\
\text { Renal vascular injury }\end{array}$ & Lameire (2014) \\
\hline & Ifosfamide & $\begin{array}{l}\text { Proximal tubular Dysfunction } \\
\text { Fanconi-like syndrome }\end{array}$ & Nissim et al. (2006) \\
\hline & Methotrexate (MTX) & $\begin{array}{l}\text { Tubular crystallization } \\
\text { ATN }\end{array}$ & Widemann and Adamson (2006) \\
\hline & Pemetrexed & $\begin{array}{l}\text { ATN } \\
\text { Nephrogenic diabetes insipidus } \\
\text { (NDI) } \\
\text { RTA }\end{array}$ & Zajjari et al. (2017) \\
\hline Contraceptive & Estrogen containing & Hemolytic uremic syndrome & Choudhury and Ahmed (2006) \\
\hline Diuretics & Thiazides, loop, potassium-sparing & Prerenal azotemia & Naughton (2008a) \\
\hline Immunomodulatory & Intravenous immunoglobulin (IVIG) & Osmotic nephrosis & Levy and Pusey (2000) \\
\hline Immunosuppressive & $\begin{array}{l}\text { Cyclosporin } \\
\text { Cyclosporin, tacrolimus and } \\
\text { muromonab-CD3 }\end{array}$ & $\begin{array}{l}\text { Decreased glomerulus filtration rate } \\
\text { Thrombotic microangiopathy } \\
\text { Renal vascular injury }\end{array}$ & $\begin{array}{l}\text { Busauschina et al. (2004) } \\
\text { Olyaei et al. (2001) }\end{array}$ \\
\hline Narcotic analgesic & Cocaine, heroin, methadone & Rhabdomyolysis & $\begin{array}{l}\text { Alinejad et al. (2016) and McCann } \\
\text { et al. (2002) }\end{array}$ \\
\hline Non-narcotic analgesic & $\begin{array}{l}\text { Aspirin, acetaminophen } \\
\text { Nonsteroidal anti-inflammatory drugs }\end{array}$ & $\begin{array}{l}\text { Chronic interstitial nephritis } \\
\text { Glomerulonephritis } \\
\text { Acute interstitial nephritis } \\
\text { Chronic interstitial nephritis } \\
\text { Prerenal azotemia } \\
\text { Acute papillary necrosis } \\
\text { Membranous nephropathy }\end{array}$ & $\begin{array}{l}\text { Sampathkumar et al. (2016) } \\
\text { Lucas et al. (2019) and Naughton } \\
\text { (2008a) }\end{array}$ \\
\hline Osmotic agents & Mannitol, dextran & $\begin{array}{l}\text { Isometric vacuolization } \\
\text { Swelling of proximal tubule }\end{array}$ & Choudhury and Ahmed (2006) \\
\hline Thrombolytic agents & $\begin{array}{l}\text { Streptokinase and tissue-plasminogen } \\
\text { activator }\end{array}$ & $\begin{array}{l}\text { Renal tissue ischemia } \\
\text { Necrosis } \\
\text { Infarction }\end{array}$ & Eddy and Fogo (2006) \\
\hline
\end{tabular}

C and gemcitabine; Table 1) (Choudhury and Ahmed 2006). The narrow arteries of the kidney including glomerular capillaries, and interlobular and arcuate arteries can be clogged by arterial cholesterol plaques following administration of thrombolytic agents (e.g., streptokinase) and anticoagulants (e.g., warfarin). This can result in ischemia, infarction, necrosis, and inflammation of the surrounding interstitium, often also affecting tubular cells leading to acute tubular necrosis (ATN; Table 1) (Hitti and Anderson 2005).

\section{Tubular injury}

Proximal tubule cells absorb and concentrate compounds from the glomerular filtrate as well as from the systemic circulation, and are prone to be affected by nephrotoxic drugs. These drugs can cause tubular toxicity by various mechanisms such as oxidative stress, diminishing mitochondrial function, restricting tubular transport processes, and generating oxidative stress (Perazella 2005). Drugs such as antimicrobials, chemotherapeutics, radiocontrast agents, immunosuppressives, and bisphosphonates are associated with tubular injury. These xenobiotics disrupt tubular cell polarity which, along with the expression of apical and basolateral transporters, is crucial for tubular cell function. This leads to the dislocation of apical and basolateral transporters (e.g., Na/K-ATPase) resulting in a leaky epithelium. Furthermore, subsequent increase in intracellular calcium disrupts ion homeostasis, leading to cell death (Lameire et al. 2005). 


\section{Inflammation}

Induction of inflammatory responses in the glomerulus, renal tubular cells, and the surrounding interstitium is another mechanism of drug-induced nephrotoxicity that can lead to fibrosis and renal scarring (Naughton 2008b). An immunemediated inflammatory condition, glomerulonephritis, has been reported to be induced by several medications such as penicillin and NSAIDs (Table 1) and is associated with proteinuria (Frazier and Obert 2018). Inflammation can also be a complication of lithium, although less well known than its tubulotoxic effects. Another inflammatory condition, acute interstitial nephritis (AIN), occurs as adverse reaction to several drugs that are assumed to induce an immune response by binding to the antigens in the kidney. Medications such as antimicrobials, phenytoin, proton-pump inhibitors, allopurinol, lithium, and antivirals have been implicated in this condition (Rossert 2001).

\section{Crystal nephropathy}

Various drugs and their derivatives may lead to precipitation of crystals within the distal tubular lumen because of their insolubility in urine, thereby restricting urine flow and triggering a cellular reaction in the interstitium. Renal insufficiency and intravascular volume depletion increase the risk of crystal nephropathy. Concentration of the drug in the urine and urinary $\mathrm{pH}$ may influence the precipitation of crystals and volume repletion and adjustment of urinary $\mathrm{pH}$, improving solubility, may be of benefit. Medications associated with crystal nephropathy include antivirals and antimicrobials as mentioned in Table 1 (Markowitz and Perazella 2005).

\section{Patient-specific risk factors}

Some patients are more susceptible to develop drug-induced nephrotoxicity. Volume depletion increases the risk by changing the drug concentration to a toxic level. Hypoalbuminemia, commonly observed in cirrhotic patients, increases the risk of unwanted drug overdose by elevating the serum concentration of the unbound drug fractions (Pazhayattil and Shirali 2014). Both elderly and neonates possess a particular risk for drug-induced nephrotoxicity. Comorbid conditions and administration of multiple nephrotoxic drugs carry a significant burden to elderly patients, while premature delivery predisposes neonates to develop kidney function impairment (Patzer 2008). In addition, individual genetic makeup, responsible for variable metabolic pathways and related drug sensitivity, can also influence the vulnerability of kidneys to nephrotoxicants. Polymorphisms in genes encoding enzymes that are involved in drugs' metabolism and elimination processes may increase the risk of nephrotoxicity. For instance, polymorphism of cytosolic glutathione-S-transferase (GST) enzyme elevates the risk for cisplatin-induced nephrotoxicity, since this enzyme can, to a certain extent, detoxify reactive molecules (Petros et al. 2005). A systematic review on inter-individual differences in cisplatin-induced nephrotoxicity has recently pointed towards three genes (SLC22A2, and two DNA repair genes) that determine sensitivity, suggesting that patient-specific dose optimization can be applied according to the genetic makeup. This approach could possibly reduce cisplatin toxicity (Zazuli et al. 2019).

\section{Kidney failure due to remote organ damage}

Several risk factors such as genetics, obesity, diabetes, cardiovascular disease, and age can increase the chances of an individual to develop kidney disease, or when already diagnosed, it can gradually drive the progression of the disease (Kazancioğlu 2013). It is important to note that renal dysfunction can also be affected by the performance of distinct organs, such as the heart, lung, and liver. As the kidneys receive $\sim 25 \%$ of the cardiac output, a condition known as cardiorenal syndrome (CRS) can manifest when either the heart or the kidneys fail (Ronco et al. 2012). Considering that some segments of the nephron are highly sensitive to oxygen variations, if the lung is injured it can cause severe hypoxemia which in time can reduce renal blood flow, contributing to renal impairment as well (Basu and Wheeler 2013). Patients suffering from cirrhosis can develop hepatorenal syndrome (HRS), which can lead to damage and degeneration of the kidney. If the hepatic metabolism is compromised, a downregulation of cytochrome P450 (CYP) enzymes activity can lead to an accumulation of nephrotoxic drugs in the systemic circulation, resulting in kidney injury (Lane et al. 2013).

\section{Biomarkers for drug-induced kidney injury}

Creatinine and urea have long been considered as the "gold standard" to identify drug-induced nephrotoxicity and to detect renal dysfunction. However, various limitations of these two biomarkers, including low sensitivity and specificity, delayed rise in plasma because of functional reserve, and extrarenal clearance, demand for novel renal biomarkers to early detect and monitor drug-induced nephrotoxicity with high specificity and sensitivity. To address this, new potential markers are continuously being developed and qualified, resulting in a substantial increase of biomarker research (Xie et al. 2013). Until now, several biomarkers have been identified, as enlisted in Table 2. A biomarker qualification data submission released by the Predictive Safety Testing Consortium (PSTC) in 2009 included urinary kidney injury molecule-1 (KIM-1), urinary trefoil factor 3 (TFF-3), urinary beta-2 microglobulin (B2 M), urinary cystatin C (CysC), 
Table 2 Overview of renal toxicitv biomarkers

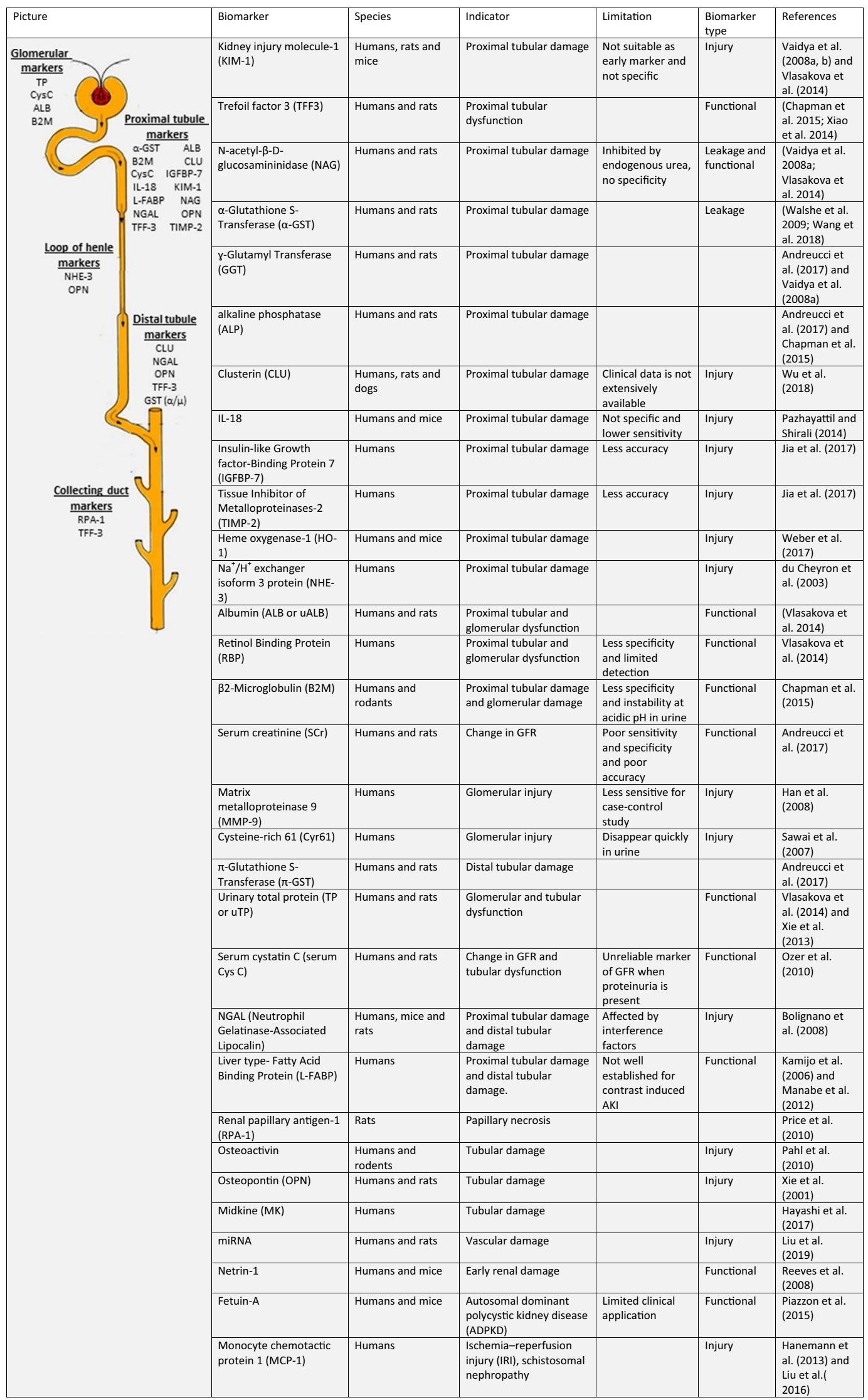


urinary albumin (uALB), urinary total protein (uTP), and urinary clusterin (CLU) as emerging biomarkers to study xenobiotic-induced kidney injury in rat (Dieterle et al. 2010b). Later in 2014, with the support of Food and Drug Administration (FDA) and European Medicines Agency (EMA), the PSTC included neutrophil gelatinase-associated lipocalin (NGAL) and osteopontin (OPN) for further evaluation as emerging biomarkers (Dieterle et al. 2010b).

KIM-1, a sensitive and specific damage marker of proximal tubule epithelial cells, can cleave and move into the tubule lumens upon diverse primary and secondary renal damages. It is found up-regulated in CKD with renal fibrosis and is significantly elevated in early stages of AKI. It is considered an early marker for detection, progression, and outcome of kidney diseases. However, increased KIM-1 may also play role in renal tubular epithelial cells' regeneration after acute injury (Xie et al. 2013; Yin and Wang 2016). One of the least studied, biologically qualified urinary markers is TFF3, which is reduced significantly in a time- and dose-dependent manner following proximal tubular damage. This small peptide hormone is also found to correlate with the severity of kidney lesions and is considered as a sensitive marker for AKI (Yu et al. 2010). B2M is a low molecular-weight protein filtered completely and almost completely reabsorbed by the proximal tubule. Therefore, a significant increase of $\mathrm{B} 2 \mathrm{M}$ is observed in urine following a minor impairment in tubular uptake. Thus, urine B2M is considered as a potential indicator of impaired function during drug-induced nephrotoxicity. In addition, glomerular injury can also elevate urinary excretion of B2M and it has, therefore, been qualified as glomerular injury marker as well in rodents (Dieterle et al. 2010a). Contrary to the conventional renal function biomarkers, CysC exhibits high sensitivity and specificity in monitoring acute and chronic renal impairments. Determination of CysC levels can be used to diagnose early stages of renal dysfunction and to monitor functional alterations over time. This biomarker is considered a better diagnostic tool for pre-clinical renal disease and is found to be a more accurate detector of early stage diabetic nephropathy (Onopiuk et al. 2015). Its plasma level is used as glomerular marker for GFR and the urine level as functional marker of proximal tubule, since it is a low-molecular-weight protein that needs to be reabsorbed by megalin. Urinary albumin (uALB) has been considered a well-established diagnostic and prognostic marker to study the extent of glomerular injury in CKD. Because of its specificity to intrinsic causes such as rhabdomyolysis and ischemic-reperfusion, it remains unchanged in prerenal and postrenal events of AKI (Bolisetty and Agarwal 2011).

Another early marker of renal damage is urinary clusterin (CLU), which is a heterodimeric glycoprotein that contributes to cellular interaction, lipid transport, and initiation of apoptosis during renal damage. Like KIM-1, expression of
CLU is significantly elevated in dedifferentiated tubular cells during AKI but also in polycystic kidney disease, nephrectomy, and renal cell carcinoma (Hidaka et al. 2002). This marker has been found as a promising indicator of tubulointerstitial renal lesions and able to predict end-stage kidney disease (ESKD) (Wu et al. 2018), and also helps in triaging of patients with delayed graft function in less than $4 \mathrm{~h}$ after transplantation (Pianta et al. 2015). A lysosomal enzyme of proximal tubule, $N$-acetyl- $\beta$-glucosaminidase (NAG), is a persistent, sensitive, quantitative and robust biomarker of proximal tubular injury. It has been found elevated following kidney diseases such as AKI, diabetic nephropathy, and chronic glomerular diseases (Vaidya et al. 2008a). Some other enzymes, such as GST, $\boldsymbol{\gamma}$-glutamyl-transferase (GGT), and alkaline phosphatase (ALP), released from proximal and distal tubule cells into urine relate to early damage. In AKIs, two subtypes of GST, $\alpha$ and $\pi$, are released from proximal and distal tubule, respectively, allowing to distinguish between the two segments when affected (Wang et al. 2018). As GGT and ALP increase during damage in the brush border, elevated levels of these enzymes were associated with complicated pyelonephritis and renal impairment (Han et al. 2019).

\section{Models for nephrotoxicity screening}

\section{Conventional in vitro models}

Until recently, researchers were left with only two options: in vitro cultures of primary human cells or the use of animal models, both having limitations. Primary cells are used as they mimic the physiological state of cells in vivo most closely; however, these cells have a limited growth capacity and tend to lose their phenotype over time (Table 3). Despite these limitations, primary renal cells still remain a reliable option to study basic renal cellular functions and the effects of nephrotoxicants thereon. To overcome the difficulty in culturing primary cells, immortalized cells can be used because of their capacity to grow and divide indefinitely. The disadvantages of these cells include the immortalization procedure that by itself may result in some changes that, over time, can alter the functions and characteristics of cells (Bajaj et al. 2018). Animal models are used as they can fill the gap that in vitro models often have, viz, the lack of physiological resemblance. However, the use of animal models is expensive, requires a lot of time and expertise, has low throughput potential, poses ethical issues, but most importantly, these models often do not correlate to human systems (Barré-Sinoussi and Montagutelli 2015).

Being the proximal tubule a major target for many nephrotoxicants, it is logical that cell-based in vitro models that seek to resemble this segment of the nephron should 
be characterized by the expression of important markers, including SLC22A6 (OAT1), SLC22A8 (OAT3), SLC22A2 (OCT2) on the basolateral membrane and $A B C B 1$ (P-gp), SLC47A1 (MATE1), SLC47A2 (MATE2), ABCC2 (MRP2), $A B C C 4$ (MRP4), $A B C G 2$ (BCRP), and the endocytosis receptors megalin and cubilin on the apical membrane (Bajaj et al. 2018) (Fig. 2). Although often applied, the immortalized HK-2 cell line lacks the expression of OAT1, OAT3, OCT2, MRP2, and BCRP, and may be not a representative model to study nephrotoxicity (Jenkinson et al. 2012b).

Two important immortalized cell lines have been extensively used for nephrotoxicity screening: RPTEC/TERT1 and ciPTEC. The RPTEC/TERT1 cell line was immortalized using the human telomerase reverse transcriptase (hTERT) (Simon-Friedt et al. 2015), whereas ciPTEC lines obtained either from urine or kidney tissue were transfected using hTERT and a temperature-sensitive mutant of SV large T antigen (SV40T), allowing these cells to proliferate at $33^{\circ} \mathrm{C}$ and mature at $37^{\circ} \mathrm{C}$ (Jansen et al. 2014; Wilmer et al. 2010) (Table 3 ). These cell lines surpass HK-2 cells by expressing all relevant markers cited above; however, OAT function was only attained after lentiviral transduction (Nieskens et al. 2016). Using the same immortalization procedure in the ciPTEC line, a podocyte cell line (CIHP) was generated. As these cells maintain the filtration barrier of the glomeruli, it is expected that they will also be targets of nephrotoxicants that can ultimately lead to nephrotic syndrome, although no data are as of yet available on drug effects in this cell line (Sakairi et al. 2010).

Toxicity assays mainly focus on measuring cell death; however, renal toxicity can also be manifested by changes in cell polarity, membrane integrity, and mitochondrial function. With this in mind, Sjögren et al. developed a machine learning model that allowed screening of 62 drugs in which ciPTEC-OAT1 cell line was used to predict their nephrotoxicity based on multiple parameters (Sjögren et al. 2018). Similarly, Secker et al. made use of the RPTEC/TERT1 cell line to evaluate transepithelial transports in a small set of known nephrotoxic and non-nephrotoxic drugs, demonstrating that further evaluation of functional parameters, including transepithelial electrical resistance (TEER), reabsorption, and secretion of solutes, is essential to understand the nephrotoxicity mechanisms of drugs and predict the in vivo implication in regards to kidney performance (Secker et al. 2019).

\section{Advanced in vitro models}

To bypass the limitations of $2 \mathrm{D}$ cultures, advanced in vitro culture systems have been developed, including the use of 3D organized structures, known as organoids, and kidney microphysiological systems (MPS) that can recreate fluidic characteristics found in vivo (Fig. 4). Organoids can be cultured from different sources of stem cells, including embryonic stem cells (ESC), induced pluripotent stem cells (iPSC), and adult stem cells. Due to ethical concerns regarding the culture of embryonic stem cells, iPSCs and adult stem cells are preferred. Using human iPSC cells (Table 3 ), it is possible to generate kidney organoids that contain cell types from different nephron segments; however, the generated cells are not fully mature (Takasato et al. 2015). To overcome this problem, Chuva et al. developed a two-step protocol in which kidney organoids were transplanted into a chick chorioallantoic membrane to provide a vascularized environment that is necessary for the further maturation of the organoids (Chuva de Sousa Lopes 2019). Examples of other 3D culture systems include RPTEC/TERT1 and Nki-2 cells that, when cultured in Matrigel or Matrigel mixed with collagen I, respectively, were able to further mature and form tubular structures as seen in vivo. Both models showed increased sensitivity to known nephrotoxic drugs when compared to 2D cultures (Desrochers et al. 2013; Secker et al. 2017).

In line with these 3D culture systems, a bioengineered kidney tubule was developed that mimics the physiological geometry of the nephron segment. Briefly, ciPTEC-OAT1 cells were seeded onto polyethersulfone (PES) hollow fiber membranes (HFM; Table 3), previously double-coated with 3,4-dihydroxyl-L-phenylalanine (L-DOPA) and collagen IV. Using this system, the excretion of protein-bound uremic toxins and reabsorption of albumin were shown under perfusion conditions, thus mimicking the in vivo situation (Jansen et al. 2015, 2016b) and revealing a remote sensing and signaling pathway to balance microbial metabolite levels in the human body (Jansen et al. 2019). Furthermore, attenuation of uremic toxin-induced damage by vitamin $\mathrm{D}$ activated by the bioengineered kidney tubules was demonstrated (Mihajlovic et al. 2017). The use of decellularized kidneys (Table 3) can also be a suitable platform for studying druginduced nephrotoxicity. Fedecostante et al. decellularized surplus rat kidneys using sodium dodecyl sulfate (SDS) and recellularized these with ciPTEC-OAT1. An increased sensitivity to cisplatin, tenofovir, and cyclosporin A was shown for this model as compared to the 2D system (Fedecostante et al. 2017).

For further improvement of these in vitro models, implementation of fluid flow and vasculature is crucial, not only to increase maturation of the kidney cells but also to provide an environment that more closely resembles the in vivo situation. Flow in tubular lumens varies between 0.2 and 2.0 dyne $/ \mathrm{cm}^{2}$ (Cai et al. 2000) and triggers mechanosensitive pathways via microvilli, primary cilia, and the glycocalyx, all expressed at the tubular apical membrane (Raghavan and Weisz 2016). Advances in microelectromechanical systems (MEMs) allowed researchers to apply microfluidics in cell and tissue cultures that resulted in the so-called 


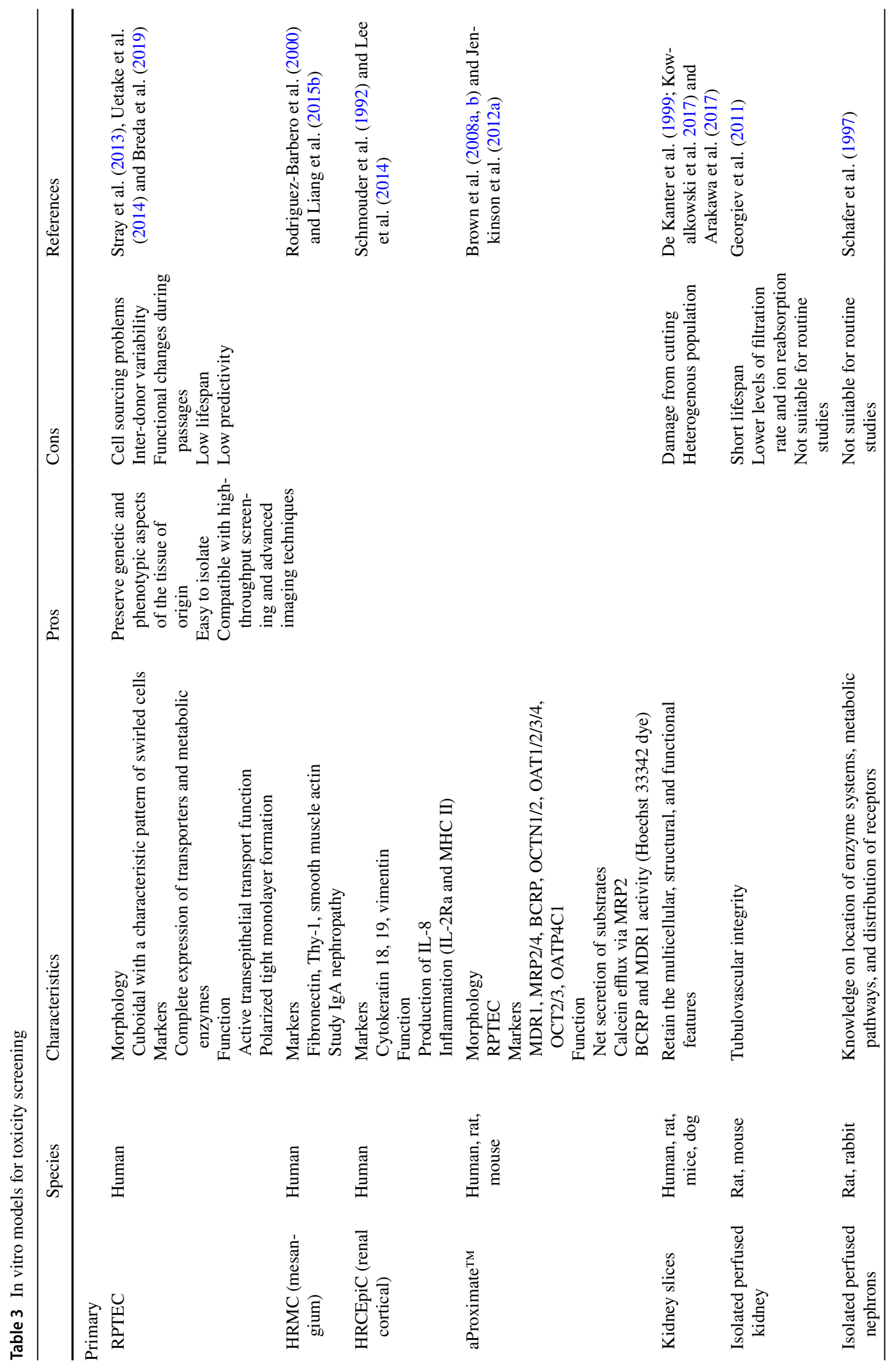




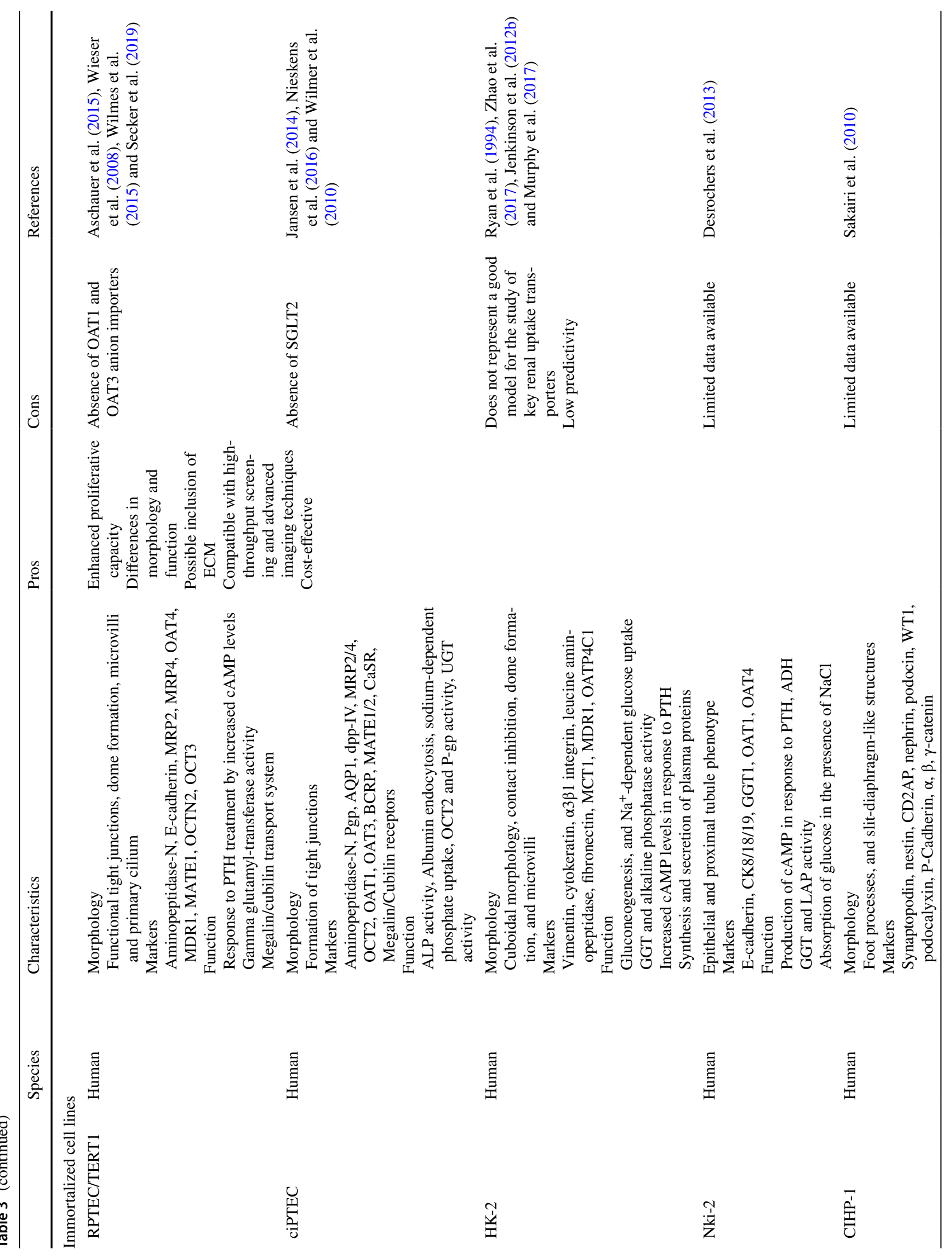




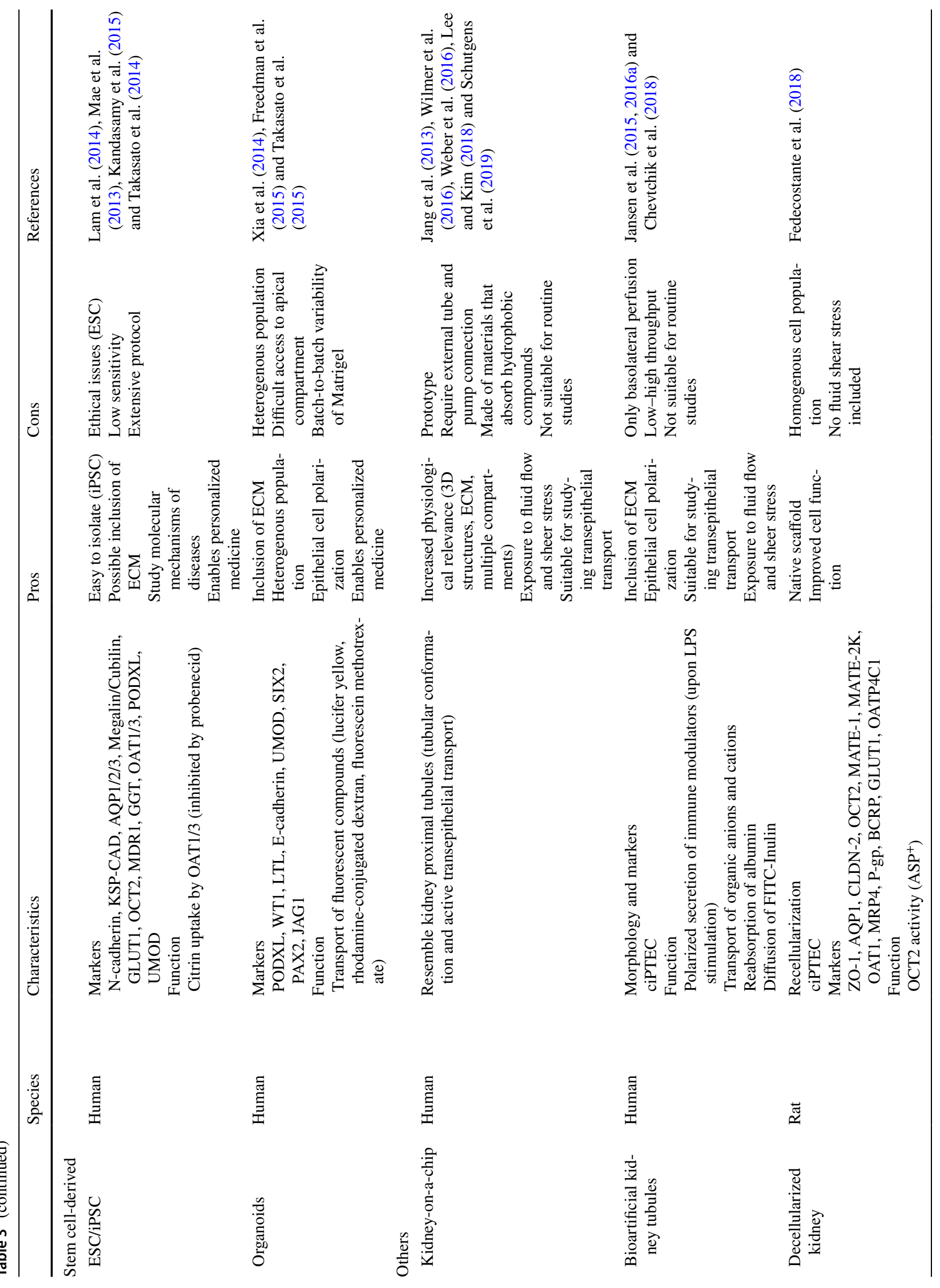


Fig. 4 Schematic figure of the different in vitro models developed for use in nephrotoxicity screenings

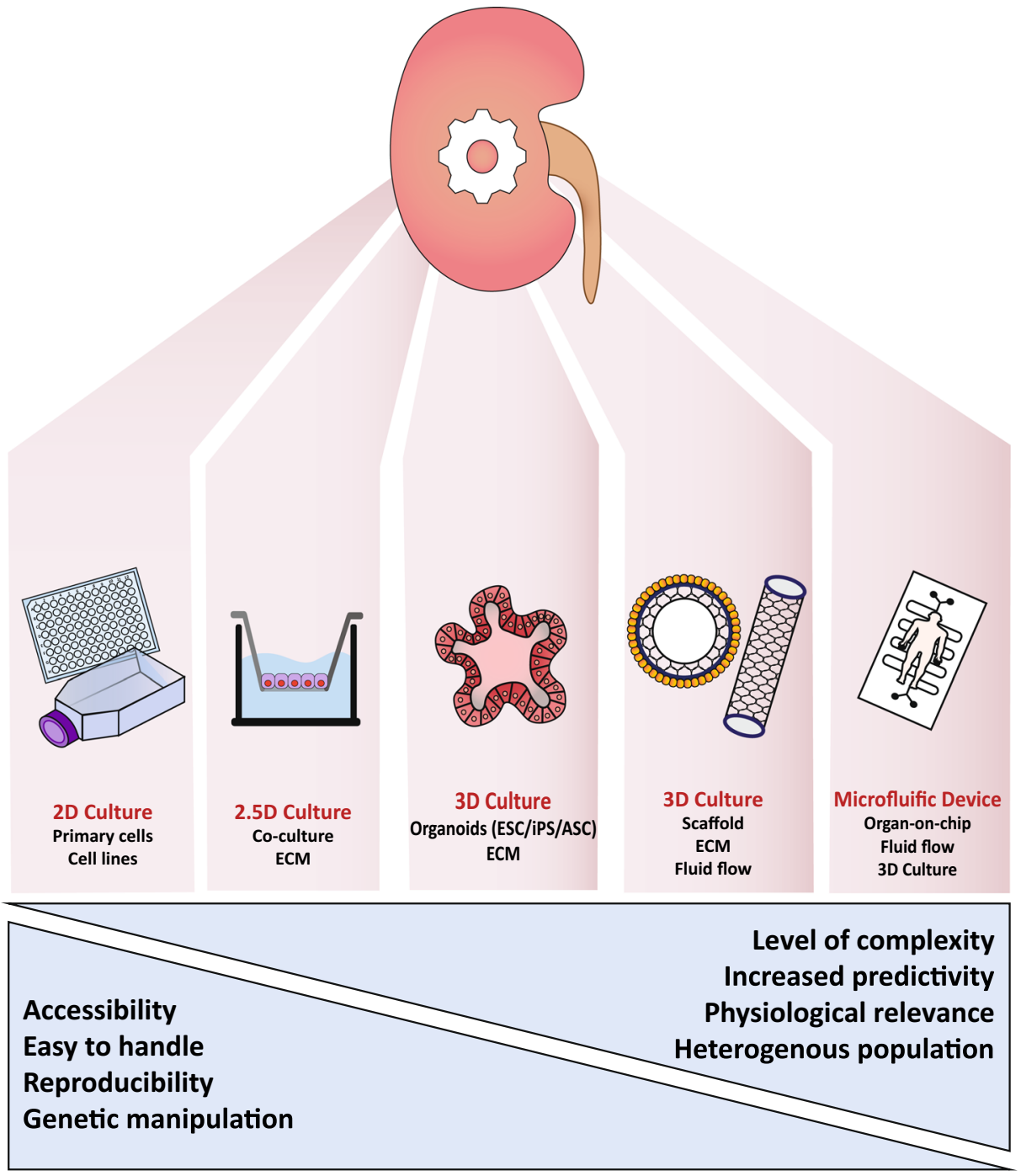

organ-on-a-chip (Table 3). Vriend et al. demonstrated that culturing ciPTEC-OAT1 in an OrganoPlate, a 3D platform consisting of 96 chips that provides fluid shear stress by placing the plate on a rocker platform, it was possible to create a high-throughput screening method compatible with advanced imaging techniques (Vriend et al. 2018). Following a similar approach, Schutgens et al. developed a new microfluidic in vitro system using kidney tubular epithelial organoids, or "tubuloids", derived from adult stem cells. The generated tubuloids showed active transepithelial transport function and were used to model several diseases, including BK virus, Wilms tumor, and cystic fibrosis, showing the great potential of this culture system for disease modeling and the possibility to use it for drug screening (Schutgens et al. 2019).

A lack of vascularization could potentially be overcome by the use of a 3D-print chip that combines hPSC-derived kidney organoids co-cultured with glomerular microvascular endothelial cells (GMECs) in a gelatin-fibrin ECM, as recently reported (Homan et al. 2016, 2019). The researchers showed an improved maturation of the kidney organoids when cultured under flow and in the presence of vascularization. Later, the same microfluidic platform was used to study active reabsorption of solutes between proximal tubule epithelial cells and vascular epithelium, and for the study of hyperglycemic conditions.

As mentioned before, the kidney also interacts with and reacts on remote organs. The liver and the kidney are two very complex organs that together lead to the metabolism and excretion of drugs, respectively. To predict biotransformation (liver) and elimination (kidney) in humans is a rather difficult task to achieve using normal 2D cultures (Chang et al. 2016); however, the combination of these two complex organs in an organ-on-a-chip platform made it possible to study the toxic effects of aristolochic acid I, a well-known nephrotoxicant that requires first hepatic bioactivation (Chang et al. 2017). Table 3 summarizes the different in vitro models discussed to study drug-induced 
nephrotoxicity. Together, the findings suggest that the development and use of advanced in vitro kidney models are important improvements in renal drug safety assessment.

\section{Perspectives in in vitro models' development}

Renal clearance is an important route of drug elimination from the bloodstream, mainly facilitated by the proximal tubule, which renders proximal tubule epithelial cells prone to drug-induced kidney injury. Mimicking the in vivo environment by including extracellular matrix (ECM) components, three-dimensional (3D) architectural features, a heterogeneous cellular composition and incorporating fluid shear stress in an in vitro kidney model could improve prediction of injury after drug exposures. These features need to be taken into consideration when trying to develop new in vitro models. The complex renal ECM, recently reviewed in (van Genderen et al. 2018), is in constant remodeling, especially in the transition of healthy to disease state, such as fibrosis. As fibrosis affect the different compartments of the kidney, a comprehensive analysis of the renal ECM is crucial to study the pathophysiology of the disease and its specific biomarkers (Bülow and Boor 2019). As stated before, shear stress triggers mechanosensitive pathways via microvilli, cilia, and the glycocalyx. Understanding how these structures coordinate with each other in response to flow will broaden our knowledge and help identify new molecular targets of diseases (Raghavan and Weisz 2016). Combining these features in a 3D model that includes tubule curvature (Yu et al. 2018) will allow for a better cell polarization and enhanced expression of cell markers.

Currently, in pre-clinical safety assessment studies, only a limited number of drug candidates (2-8\%) are being rejected because of nephrotoxicity (Cook et al. 2014; Guengerich 2011). A survey among pharmaceutical companies showed that the majority of drug candidates displaying nephrotoxicity in clinical trials did not show nephrotoxicity in preclinical trials (Troth et al. 2019). It is thus apparent that the currently used strategies to predict drug-induced injury warrant strong improvements. Immortalized cell lines, like ciPTEC, represent a steady and reproducible cell source for in vitro models, but are derived from one single donor and show significant changes in cell function and morphology compared to primary cells (Astashkina et al. 2012). Baseline levels of injury marker KIM-1 were 20-fold higher in immortalized cells compared to primary cells (Sakolish et al. 2018). In addition, immortalized cell lines often show chromosomal instability, as demonstrated for ciPTEC-OAT1 without affecting cell function or posing a tumorigenic risk (Mihajlovic et al. 2019), and represent a homogenous population instead of a genetic diverse population. Therefore, new sources for kidney cells emerged in the past decade. Stem cell-derived tubular cells can be obtained from multiple donors and may have potential for studying nephrotoxicity in a heterogeneous population (Wnorowski et al. 2018). Well-defined protocols to establish kidney organoids of renal tubular epithelial cells from induced pluripotent stem cells (iPSCs) derived from fibroblasts are now available (Czerniecki et al. 2018; Freedman et al. 2015; Kaminski Michael et al. 2016; Morizane et al. 2015; Takasato et al. 2015). In these cultures, typical proximal tubule cell characteristics have been demonstrated, such as albumin uptake, expression of tight junction proteins, expression of OAT1, microvilli, and apical and basolateral membrane polarization. In addition, cytotoxicity was demonstrated using cisplatin (Czerniecki et al. 2018; Freedman et al. 2015; Kaminski Michael et al. 2016; Morizane et al. 2015; Takasato et al. 2015), gentamicin (Freedman et al. 2015; Kaminski Michael et al. 2016; Morizane et al. 2015), tacrolimus (Kaminski Michael et al. 2016), and adriamycin (Kumar et al. 2019). As earlier stated, kidney tubuloids grown from adult stem cells (ASCs) are another promising approach as they allow for long-term culturing and better maturation without losing chromosomal stability (Schutgens et al. 2019).

To model kidney diseases, direct pathogen exposure and genome editing have been applied, depending on the cause of disease. Effects of Shiga toxin 2, a cytotoxic protein causing hemolytic-uremic syndrome (HUS), were studied in a 3D model of renal cortical epithelial cells (DesRochers et al. 2015). And polycystic kidney disease was studied via CRISPR-Cas9 genome editing of PC-1 and -2 in iPSCderived kidney organoids (Czerniecki et al. 2018; Freedman et al. 2015). Personalized medicine allows for studying disease progression and testing treatment options in a tailor-made fashion via obtaining tissue from kidney disease patients. ASCs-derived tubuloids from Wilms tumors elucidated an important role for SIX2, a kidney development marker (Kobayashi et al. 2008; Schutgens et al. 2019). Furthermore, tubuloids obtained via urine from cystic fibrosis patients were used to assess treatment efficacy and circumvented the use of an invasive method to obtain patient material (Schutgens et al. 2019). Furthermore, the dynamic process of kidney stone formation was studied in HK-2 cells cultured in a microfluidic device, which allowed real-time monitoring of calcium phosphate deposition in the lumen (Wei et al. 2012).

Improving predictability of in vitro models fits also in the scope of the 3Rs (replacement, reduction, refinement) of animal experiments. This could reduce costs of the preclinical and clinical phases of drug development by filtering out the harmful compounds. However, more importantly, it also meets the societal demands to reduce the number of animals in drug development. Drug regulatory authorities, such as FDA and EMA, support the use of physiologically based pharmacokinetic (PBPK) modeling as a tool to facilitate the process of drug development. In vitro-to-in vivo 
extrapolation (IVIVE) can be coupled with PBPK modeling as a way to predict the in vivo pharmacokinetic characteristics of a new drug based on in vitro studies. In vitro studies can provide information regarding drug-enzyme and drug-transporter interactions. However, the full understanding of the absorption, distribution, metabolism, and excretion (ADME) processes is not feasible. By extrapolating complex scenarios observed in vitro while having in mind that intrinsic and extrinsic factors can alter the kinetic values, one can identify optimal dosing regimens for individual patients (Rostami-Hodjegan 2012; Zhao et al. 2011; van der Made et al. 2019).

\section{Conclusions}

Nephrotoxicity is associated with significant mortality and morbidity. Undoubtedly, drug-induced nephrotoxicity is a major cause of renal impairments and a potential impediment to the research and development of drugs, requiring more reliable and early diagnosis to avoid potentially fatal chronic conditions. To date, there is no ideal kidney-based in vitro model for the study of nephrotoxicity; however, we are moving towards more advanced in vitro culture systems that offer great promise for the assessment of drug toxicity. These new models include several characteristics that are important for the successful toxicologic read-out of drug candidates, including 3D architectural features, ECM components, fluid flow, and multiple cell types combined. Despite the promising advances of these models, appropriate toxicity end-points and sensitive translational biomarkers are yet to be identified. Current efforts remain as "bench-work" and do not reach the "bed-side". Therefore, there is a pressing need to systematically combine in vitro, in vivo, and clinical inspections to develop a panel of safety biomarkers that can effectively and reliably diagnose and monitor renal function, damage, and recovery.

Acknowledgements This study has received funding from the European Union's Horizon 2020 research and innovation programme under the Marie Skłodowska-Curie Grant agreement no. 813839.

\section{Compliance with ethical standards}

Conflict of interest The authors declare no conflicts of interest with the contents of this article.

Open Access This article is distributed under the terms of the Creative Commons Attribution 4.0 International License (http://creativeco mmons.org/licenses/by/4.0/), which permits unrestricted use, distribution, and reproduction in any medium, provided you give appropriate credit to the original author(s) and the source, provide a link to the Creative Commons license, and indicate if changes were made.

\section{References}

Alinejad S, Ghaemi K, Abdollahi M, Mehrpour O (2016) Nephrotoxicity of methadone: a systematic review. Springerplus 5(1):2087. https://doi.org/10.1186/s40064-016-3757-1

Anders MW (1980) Metabolism of drugs by the kidney. Kidney Int 18:636-647. https://doi.org/10.1038/KI.1980.181

Andreucci M, Faga T, Pisani A, Perticone M, Michael A (2017) The ischemic/nephrotoxic acute kidney injury and the use of renal biomarkers in clinical practice. Eur J Intern Med 39:1-8. https ://doi.org/10.1016/j.ejim.2016.12.001

Arakawa H, Washio I, Matsuoka N et al (2017) Usefulness of kidney slices for functional analysis of apical reabsorptive transporters. Sci Rep 7:12814. https://doi.org/10.1038/s41598-01712828-z

Aschauer L, Limonciel A, Wilmes A et al (2015) Application of RPTEC/TERT1 cells for investigation of repeat dose nephrotoxicity: a transcriptomic study. Toxicol In Vitro 30:106-116. https://doi.org/10.1016/J.TIV.2014.10.005

Astashkina A, Mann B, Grainger DW (2012) A critical evaluation of in vitro cell culture models for high-throughput drug screening and toxicity. Pharmacol Ther 134(1):82-106. https://doi. org/10.1016/j.pharmthera.2012.01.001

Azab AN, Shnaider A, Osher Y, Wang D, Bersudsky Y, Belmaker RH (2015) Lithium nephrotoxicity. Int J. Bipolar Disord 3(1):28. https://doi.org/10.1186/s40345-015-0028-y

Bajaj P, Chowdhury SK, Yucha R, Kelly EJ, Xiao G (2018) Emerging kidney models to investigate metabolism, transport, and toxicity of drugs and xenobiotics (1521-009X (Electronic))

Barnett LMA, Cummings BS (2018) Nephrotoxicity and renal pathophysiology: a contemporary perspective. Toxicol Sci 164:379390. https://doi.org/10.1093/toxsci/kfy 159

Barré-Sinoussi F, Montagutelli X (2015) Animal models are essential to biological research: issues and perspectives. Future Sci OA 1(4):FSO63. https://doi.org/10.4155/fso.15.63

Basile DP, Anderson MD, Sutton TA (2012) Pathophysiology of acute kidney injury. Compr Physiol 2:1303-1353. https://doi. org/10.1002/cphy.c110041

Basu RK, Wheeler DS (2013) Kidney-lung cross-talk and acute kidney injury. Pediatr Nephrol (Berlin, Germany) 28:2239-2248. https://doi.org/10.1007/s00467-012-2386-3

Bello-Reuss E, Reuss L (1983) Homeostatic and excretory functions of the kidney the kidney and body fluids in health and disease. Springer, Boston, pp 35-63

Bird ST, Etminan M, Brophy JM, Hartzema AG, Delaney JA (2013) Risk of acute kidney injury associated with the use of fluoroquinolones. CMAJ Can Med Assoc J journal de l'Association medicale canadienne 185(10):E475-E482. https://doi. org/10.1503/cmaj.121730

Bolignano D, Donato V, Coppolino G et al (2008) Neutrophil gelatinase-associated lipocalin (NGAL) as a marker of kidney damage. Am J Kidney Dis 52(3):595-605. https://doi. org/10.1053/j.ajkd.2008.01.020

Bolisetty S, Agarwal A (2011) Urine albumin as a biomarker in acute kidney injury. Am J Physiol Renal Physiol 300(3):F626-F627. https://doi.org/10.1152/ajprenal.00004.2011

Breda PC, Wiech T, Meyer-Schwesinger C et al (2019) Renal proximal tubular epithelial cells exert immunomodulatory function by driving inflammatory CD4+ T cell responses. Am J Physiol Renal Physiol 317(1):F77-F89. https://doi.org/10.1152/ajpre nal.00427.2018

Brodsky SV (2014) Anticoagulants and acute kidney injury: clinical and pathology considerations. Kidney Res Clin Pract 33(4):174-180. https://doi.org/10.1016/j.krcp.2014.11.001 
Brown CD, Sayer R, Windass AS et al (2008a) Characterisation of human tubular cell monolayers as a model of proximal tubular xenobiotic handling. Toxicol Appl Pharmacol 233(3):428-438

Brown CDA, Sayer R, Windass AS et al (2008b) Characterisation of human tubular cell monolayers as a model of proximal tubular xenobiotic handling. Toxicol Appl Pharmacol 233:428-438. https://doi.org/10.1016/J.TAAP.2008.09.018

Bülow RD, Boor P (2019) Extracellular matrix in kidney fibrosis: more than just a scaffold. J Histochem Cytochem. https://doi. org/10.1369/0022155419849388

Busauschina A, Schnuelle P, van der Woude FJ (2004) Cyclosporine nephrotoxicity. Transpl Proc 36(2 Suppl):229s-233s. https://doi. org/10.1016/j.transproceed.2004.01.021

Cai Z, Xin J, Pollock DM, Pollock JS (2000) Shear stress-mediated NO production in inner medullary collecting duct cells. Am J Physiol Renal Physiol 279(2):F270-F274. https://doi.org/10.1152/ajpre nal.2000.279.2.F270

Chang SY, Weber EJ, Ness KV, Eaton DL, Kelly EJ (2016) Liver and kidney on chips: microphysiological models to understand transporter function. Clin Pharmacol Ther 100(5):464-478. https:// doi.org/10.1002/cpt.436

Chang S-Y, Weber EJ, Sidorenko VS et al (2017) Human liver-kidney model elucidates the mechanisms of aristolochic acid nephrotoxicity. JCI Insight 2(22):e95978. https://doi.org/10.1172/jci. insight. 95978

Chapman AB, Devuyst O, Eckardt K-U et al (2015) Autosomal-dominant polycystic kidney disease (ADPKD): executive summary from a kidney disease: improving global outcomes (KDIGO) controversies conference. Kidney Int 88(1):17-27. https://doi. org/10.1038/ki.2015.59

Chevtchik NV, Mihajlovic M, Fedecostante M et al (2018) A bioartificial kidney device with polarized secretion of immune modulators. J Tissue Eng Regen Med 12:1670-1678. https://doi. org/10.1002/term.2694

Choudhury D, Ahmed Z (2006) Drug-associated renal dysfunction and injury. Nat Clin Pract Nephrol 2(2):80-91. https://doi. org/10.1038/ncpneph0076

Coco TJ, Klasner AE (2004) Drug-induced rhabdomyolysis. Curr Opin Pediatr 16(2):206-210

Cook D, Brown D, Alexander R et al (2014) Lessons learned from the fate of AstraZeneca's drug pipeline: a five-dimensional framework. Nat Rev Drug Discovery 13:419. https://doi.org/10.1038/ $\operatorname{nrd} 4309$

Czerniecki SM, Cruz NM, Harder JL et al (2018) High-throughput screening enhances kidney organoid differentiation from human pluripotent stem cells and enables automated multidimensional phenotyping. Cell Stem Cell 22(6):929.e4-940.e4. https://doi. org/10.1016/j.stem.2018.04.022

de Chuva de Sousa Lopes SM (2019) Accelerating maturation of kidney organoids. Nat Mater 18(4):303-304. https://doi. org/10.1038/s41563-019-0326-3

De Kanter R, Olinga P, De Jager MH, Merema MT, Meijer DK, Groothius GM (1999) Organ slices as an in vitro test system for drug metabolism in human liver, lung and kidney. Toxicol In Vitro 13(4-5):737-744

Deray G (2002) Amphotericin B nephrotoxicity. The Journal of antimicrobial chemotherapy 49(Suppl 1):37-41. https://doi. org/10.1093/jac/49.suppl_1.37

Desrochers T, Suter-Dick L, Roth A, Kaplan D (2013) Bioengineered 3D human kidney tissue, a platform for the determination of nephrotoxicity. PLoS One 8:e59219. https://doi.org/10.1371/ annotation/fb32f1b8-7397-40be-bbf9-b80e67763043

DesRochers TM, Kimmerling EP, Jandhyala DM et al (2015) Effects of Shiga toxin type 2 on a bioengineered three-dimensional model of human renal tissue. Infect Immun 83(1):28-38. https://doi. org/10.1128/IAI.02143-14
Dieterle F, Perentes E, Cordier A et al (2010a) Urinary clusterin, cystatin $\mathrm{C}$, beta2-microglobulin and total protein as markers to detect drug-induced kidney injury. Nat Biotechnol 28(5):463-469. https ://doi.org/10.1038/nbt.1622

Dieterle F, Sistare F, Goodsaid F et al (2010b) Renal biomarker qualification submission: a dialog between the FDA-EMEA and Predictive Safety Testing Consortium. Nat Biotechnol 28(5):455-462. https://doi.org/10.1038/nbt.1625

Dixit M, Doan T, Kirschner R, Dixit N (2010) significant acute kidney injury due to non-steroidal anti-inflammatory drugs: inpatient setting. Pharmaceuticals (Basel, Switzerland) 3:1279-1285. https ://doi.org/10.3390/ph3041279

du Cheyron D, Daubin C, Poggioli J et al (2003) Urinary measurement of $\mathrm{Na}+\mathrm{H}+$ exchanger isoform 3 (NHE3) protein as new marker of tubule injury in critically ill patients with ARF. Am J Kidney Dis 42(3):497-506

Eddy AA, Fogo AB (2006) Plasminogen activator inhibitor-1 in chronic kidney disease: evidence and mechanisms of action. $\mathrm{J}$ Am Soc Nephrol 17(11):2999-3012. https://doi.org/10.1681/ asn.2006050503

Eirin A, Lerman A, Lerman LO (2017) The emerging role of mitochondrial targeting in kidney disease. Handb Exp Pharmacol 240:229-250. https://doi.org/10.1007/164_2016_6

Ejaz P, Bhojani K, Joshi VR (2004) NSAIDs and kidney. J Assoc Physicians India 52:632-640

Eshbach ML, Weisz OA (2017) Receptor-mediated endocytosis in the proximal tubule. Annu Rev Physiol 79(1):425-448. https://doi. org/10.1146/annurev-physiol-022516-034234

Fedecostante M, Onciu OG, Westphal KGC, Masereeuw R (2017) Towards a bioengineered kidney: recellularization strategies for decellularized native kidney scaffolds. Int J Artif Org 40:150 158. https://doi.org/10.5301/ijao.5000564

Fedecostante M, Westphal KGC, Buono MF et al (2018) recellularized native kidney scaffolds as a novel tool in nephrotoxicity screening. Drug Metab Dispos Biol Fate Chem 46(9):1338-1350. https ://doi.org/10.1124/dmd.118.080721

Feher J (2017) Tubular Reabsorption and Secretion. Quant Hum Physiol. https://doi.org/10.1016/b978-0-12-800883-6.00072-0

Fernandez-Fernandez B, Montoya-Ferrer A, Sanz AB et al (2011) Tenofovir nephrotoxicity: 2011 update. AIDS Res Treat 2011:354908. https://doi.org/10.1155/2011/354908

Frazier KS, Obert LA (2018) Drug-induced glomerulonephritis: the spectre of biotherapeutic and antisense oligonucleotide immune activation in the kidney. Toxicol Pathol 46(8):904-917. https:// doi.org/10.1177/0192623318789399

Freedman BS, Brooks CR, Lam AQ et al (2015) Modelling kidney disease with CRISPR-mutant kidney organoids derived from human pluripotent epiblast spheroids. Nat Commun 6:8715. https://doi. org/10.1038/ncomms9715

Frochot V, Bazin D, Letavernier E, Jouanneau C, Haymann J-P, Daudon M (2016) Nephrotoxicity induced by drugs: the case of foscarnet and atazanavir - a SEM and $\mu$ FTIR investigation. C R Chim 19(11):1565-1572. https://doi.org/10.1016/j.crci.2016.08.007

Georgiev T, Iliev R, Mihailova S et al (2011) The isolated perfused kidney models-certain aspects. Trakia J Sci 9(3):82-87

Ghane Shahrbaf F, Assadi F (2015) Drug-induced renal disorders. J Renal Inj Prev 4(3):57-60. https://doi.org/10.12861/jrip.2015.12

Giacomini KM, Huang SM, Tweedie DJ et al (2010) Membrane transporters in drug development. Nat Rev Drug Discov 9(3):215-236

Guengerich FP (2011) Mechanisms of drug toxicity and relevance to pharmaceutical development. Drug Metab Pharmacokinet 26(1):3-14

Han WK, Waikar SS, Johnson A et al (2008) Urinary biomarkers in the early diagnosis of acute kidney injury. Kidney Int 73(7):863-869. https://doi.org/10.1038/sj.ki.5002715 
Han C, Lee Y-K, Park HC et al (2019) Serum alkaline phosphatase and $\gamma$-glutamyl transferase in acute pyelonephritis. Kidney Res Clin Pract 38(2):205-211. https://doi.org/10.23876/j.krcp.18.0074

Hanemann AL, Liborio AB, Daher EF et al (2013) Monocyte chemotactic protein-1 (MCP-1) in patients with chronic schistosomiasis mansoni: evidences of subclinical renal inflammation. PLoS One 8(11):e80421. https://doi.org/10.1371/journal.pone.0080421

Hara M, Suganuma A, Yanagisawa N, Imamura A, Hishima T, Ando M (2015) Atazanavir nephrotoxicity. Clin Kidney J 8(2):137-142. https://doi.org/10.1093/ckj/sfv015

Haussler MR, Whitfield GK, Haussler CA et al (2016) 1,25-Dihydroxyvitamin D and klotho: a tale of two renal hormones coming of age. Vitam Horm 100:165-230. https://doi.org/10.1016/ BS.VH.2015.11.005

Hayashi H, Sato W, Kosugi T et al (2017) Efficacy of urinary midkine as a biomarker in patients with acute kidney injury. Clin Exp Nephrol 21(4):597-607. https://doi.org/10.1007/s1015 7-016-1318-0

Hidaka S, Kranzlin B, Gretz N, Witzgall R (2002) Urinary clusterin levels in the rat correlate with the severity of tubular damage and may help to differentiate between glomerular and tubular injuries. Cell Tissue Res 310(3):289-296. https://doi.org/10.1007/ s00441-002-0629-5

Hitti WA, Anderson J (2005) Cholesterol emboli-induced renal failure and gastric ulcer after thrombolytic therapy. South Med J 98(2):235-237. https://doi.org/10.1097/01.Smj.0000152754 12363.45

Holechek MJ (2003) Glomerular filtration: an overview. Nephrol Nurs J J Am Nephrol Nurs Assoc 30:285-290 (quiz 291-2)

Homan KA, Kolesky DB, Skylar-Scott MA et al (2016) Bioprinting of 3D convoluted renal proximal tubules on perfusable chips. Sci Rep. https://doi.org/10.1038/srep34845

Homan KA, Gupta N, Kroll KT et al (2019) Flow-enhanced vascularization and maturation of kidney organoids in vitro. Nat Methods 16(3):255-262. https://doi.org/10.1038/s41592-019-0325-y

Htike NL, Santoro J, Gilbert B, Elfenbein IB, Teehan G (2012) Biopsyproven vancomycin-associated interstitial nephritis and acute tubular necrosis. Clin Exp Nephrol 16(2):320-324. https://doi. org/10.1007/s10157-011-0559-1

Izzedine H, Launay-Vacher V, Deray G (2005) Antiviral drug-induced nephrotoxicity. Am J Kidney Dis 45(5):804-817

Jafari A, Khalili H, Dashti-Khavidaki S (2014) Tenofovir-induced nephrotoxicity: incidence, mechanism, risk factors, prognosis and proposed agents for prevention. Eur J Clin Pharmacol 70(9):1029-1040. https://doi.org/10.1007/s00228-014-1712-z

Jang KJ, Mehr AP, Hamilton GA et al (2013) Human kidney proximal tubule-on-a-chip for drug transport and nephrotoxicity assessment. Integr Biol (United Kingdom). https://doi.org/10.1039/ c3ib40049b

Jansen J, Schophuizen CMS, Wilmer MJ et al (2014) A morphological and functional comparison of proximal tubule cell lines established from human urine and kidney tissue. Exp Cell Res 323(1):87-99. https://doi.org/10.1016/j.yexcr.2014.02.011

Jansen J, De Napoli IE, Fedecostante M et al (2015) Human proximal tubule epithelial cells cultured on hollow fibers: living membranes that actively transport organic cations. Sci Rep 5:16702. https://doi.org/10.1038/srep16702

Jansen J, Fedecostante M, Wilmer MJ et al (2016a) Bioengineered kidney tubules efficiently excrete uremic toxins. Sci Rep 6:1-12. https://doi.org/10.1038/srep26715

Jansen J, Fedecostante M, Wilmer MJ et al (2016b) Bioengineered kidney tubules efficiently excrete uremic toxins. Sci Rep 6:26715. https://doi.org/10.1038/srep26715

Jansen J, Jansen K, Neven E et al (2019) Remote sensing and signaling in kidney proximal tubules stimulates gut microbiome-derived organic anion secretion. Proc Natl Acad Sci USA. https://doi. org/10.1073/pnas.1821809116

Jenkinson SE, Chung GW, van Loon E, Bakar NS, Dalzell AM, Brown CD (2012a) The limitations of renal epithelial cell line HK-2 as a model of drug transporter expression and function in the proximal tubule. Pflugers Arch 464(6):601-611

Jenkinson SE, Chung GW, van Loon E, Bakar NS, Dalzell AM, Brown CDA (2012b) The limitations of renal epithelial cell line HK-2 as a model of drug transporter expression and function in the proximal tubule. Pflügers Arch Eur J Physiol 464:601-611. https ://doi.org/10.1007/s00424-012-1163-2

Jia HM, Huang LF, Zheng Y, Li WX (2017) Diagnostic value of urinary tissue inhibitor of metalloproteinase- 2 and insulin-like growth factor binding protein 7 for acute kidney injury: a metaanalysis. Crit Care (London, England) 21(1):77. https://doi. org/10.1186/s13054-017-1660-y

Kakoki M, Smithies O (2009) The kallikrein-kinin system in health and in diseases of the kidney. Kidney Int 75:1019. https://doi. org/10.1038/KI.2008.647

Kalyesubula R, Perazella MA (2011) Nephrotoxicity of HAART. AIDS Res Treat 2011:562790. https://doi.org/10.1155/2011/562790

Kamijo A, Sugaya T, Hikawa A et al (2006) Urinary liver-type fatty acid binding protein as a useful biomarker in chronic kidney disease. Mol Cell Biochem 284(1-2):175-182. https://doi. org/10.1007/s11010-005-9047-9

Kaminski Michael M, Tosic J, Kresbach C et al (2016) Direct reprogramming of fibroblasts into renal tubular epithelial cells by defined transcription factors. Nat Cell Biol 18:1269. https://doi. org/10.1038/ncb3437

Kandasamy K, Chuah JKC, Su R et al (2015) Prediction of druginduced nephrotoxicity and injury mechanisms with human induced pluripotent stem cell-derived cells and machine learning methods. Sci Rep 5:12337. https://doi.org/10.1038/srep12337

Kazancioğlu R (2013) Risk factors for chronic kidney disease: an update. Kidney Int Suppl 3:368. https://doi.org/10.1038/KISUP .2013 .79

Kim J-H, Hwang K-H, Park K-S, Kong ID, Cha S-K (2015) Biological role of anti-aging protein Klotho. J Lifestyle Med 5:1-6. https:// doi.org/10.15280/jlm.2015.5.1.1

Kipp R, Kellerman PS (2009) Chronic kidney disease. Pathophysiol Kidney Dis Hypertens. https://doi.org/10.1016/b978-1-41604391-1.50018-7

Kobayashi A, Valerius MT, Mugford JW et al (2008) Six2 defines and regulates a multipotent self-renewing nephron progenitor population throughout mammalian kidney development. Cell Stem Cell 3(2):169-181. https://doi.org/10.1016/j.stem.2008.05.020

Koeppen BM, Stanton BA (2013) Renal physiology, 5th edn. Elsevier. ISBN: 978-0-323-08691-2

Kowalkowski K, Klapczynski M, Blomme E, Buck W, Liguori M (2017) Evaluating in vitro canine kidney slices as a renal toxicity model using nephrotoxic agents cisplatin and cadmium chloride. FASEB J 31:819.8. https://doi.org/10.1096/fasebj.31.1_suppl ement. 819.8

Kumar R, Tebben PJ, Thompson JR (2012) Vitamin D and the kidney. Arch Biochem Biophys 523:77-86. https://doi.org/10.1016/j. abb.2012.03.003

Kumar SV, Er PX, Lawlor KT et al (2019) Kidney micro-organoids in suspension culture as a scalable source of human pluripotent stem cell-derived kidney cells. Development 146(5):dev172361. https://doi.org/10.1242/dev.172361

Lam AQ, Freedman BS, Morizane R, Lerou PH, Valerius MT, Bonventre JV (2014) Rapid and efficient differentiation of human pluripotent stem cells into intermediate mesoderm that forms tubules expressing kidney proximal tubular markers. J Am Soc Nephrol JASN 25:1211-1225. https://doi.org/10.1681/ASN.2013080831 
Lameire N (2014) Nephrotoxicity of recent anti-cancer agents. Clin Kidney J 7(1):11-22. https://doi.org/10.1093/ckj/sft135

Lameire N, Van Biesen W, Vanholder R (2005) Acute renal failure. Lancet (London, England) 365(9457):417-430. https://doi. org/10.1016/s0140-6736(05)17831-3

Lane K, Dixon JJ, Macphee IAM, Philips BJ (2013) Renohepatic crosstalk: does acute kidney injury cause liver dysfunction? Nephrol Dial Transplant 28:1634-1647. https://doi.org/10.1093/ndt/gft091

Lee J, Kim S (2018) Kidney-on-a-chip: a new technology for predicting drug efficacy, interactions, and drug-induced nephrotoxicity. Curr Drug Metab 19:577-583. https://doi.org/10.2174/1389200219 666180309101844

Lee EJ, Song SA, Mun HW, Yoo KH et al (2014) Blockade of interleukin-8 receptor signalling inhibits cyst development in vitro, via suppression of cell proliferation in autosomal polycystic kidney disease (1440-1797 (Electronic))

Levy JB, Pusey CD (2000) Nephrotoxicity of intravenous immunoglobulin. QJM Mon J Assoc Physicians 93(11):751-755. https ://doi.org/10.1093/qjmed/93.11.751

Liang Y, Li S, Chen L (2015a) The physiological role of drug transporters. Protein Cell 6:334. https://doi.org/10.1007/S1323 8-015-0148-2

Liang Y, Zhang J, Zhou Y, Xing G, Zhao G, Liu Z (2015b) Proliferation and cytokine production of human mesangial cells stimulated by secretory $\operatorname{IgA}$ isolated from patients with $\operatorname{IgA}$ nephropathy. Cell Physiol Biochem 36(5):1793-1808. https:// doi.org/10.1159/000430151

Liu Y, Yin Y, Liu XZ et al (2015) Retrospective analysis of vancomycin nephrotoxicity in elderly Chinese patients. Pharmacology 95(5-6):279-284. https://doi.org/10.1159/000381783

Liu X, Guan Y, Xu S et al (2016) Early predictors of acute kidney injury: a narrative review. Kidney Blood Press Res 41(5):680700. https://doi.org/10.1159/000447937

Liu Y, Liu B, Liu Y et al (2019) MicroRNA expression profile by next-generation sequencing in a novel rat model of contrastinduced acute kidney injury. Ann Transl Med 7(8):178. https:// doi.org/10.21037/atm.2019.04.44

Lopez MLSS, Gomez RA (2010) The renin phenotype: roles and regulation in the kidney. Curr Opin Nephrol Hypertens 19:366-371. https://doi.org/10.1097/MNH.0b013e32833aff32

Lopez-Novoa JM, Quiros Y, Vicente L, Morales AI, Lopez-Hernandez FJ (2011) New insights into the mechanism of aminoglycoside nephrotoxicity: an integrative point of view. Kidney Int 79(1):3345. https://doi.org/10.1038/ki.2010.337

Lote CJ (2012) Essential anatomy of the kidney principles of renal physiology. Springer, New York, pp 21-32

Lucas GNC, Leitão ACC, Alencar RL, Xavier RMF, Daher EDF, Silva Junior GBD (2019) Pathophysiological aspects of nephropathy caused by non-steroidal anti-inflammatory drugs. J Braz J Nephrol 41:124-130

Macedo E, Mehta RL (2009) Prerenal Failure: from Old Concepts to New Paradigms. Current opinion in critical care 15:467. https:// doi.org/10.1097/MCC.0B013E328332F6E3

Mae S-I, Shono A, Shiota F et al (2013) Monitoring and robust induction of nephrogenic intermediate mesoderm from human pluripotent stem cells. Nat Commun 4:1367. https://doi.org/10.1038/ ncomms 2378

Makris K, Spanou L (2016) Acute kidney injury: definition, pathophysiology and clinical phenotypes. Clin Biochem Rev 37:85

Małyszko J, Kozłowska K, Kozłowski L, Małyszko J (2016) Nephrotoxicity of anticancer treatment. Nephrol Dial Transplant 32(6):924-936. https://doi.org/10.1093/ndt/gfw338

Manabe K, Kamihata H, Motohiro M, Senoo T, Yoshida S, Iwasaka $\mathrm{T}$ (2012) Urinary liver-type fatty acid-binding protein level as a predictive biomarker of contrast-induced acute kidney injury.
Eur J Clin Investig 42(5):557-563. https://doi.org/10.111 $1 / j .1365-2362.2011 .02620 . x$

Markowitz GS, Perazella MA (2005) Drug-induced renal failure: a focus on tubulointerstitial disease. Clin Chim Acta Int J Clin Chem 351(1-2):31-47. https://doi.org/10.1016/j. cccn.2004.09.005

Markowitz GS, Fine PL, Stack JI et al (2003) Toxic acute tubular necrosis following treatment with zoledronate (Zometa). Kidney Int 64(1):281-289. https://doi.org/10.1046/j.1523-1755.2003.00071.x

Marti H-P, Frey FJ (2005) Nephrotoxicity of rapamycin: an emerging problem in clinical medicine. Nephrol Dial Transplant 20(1):1315. https://doi.org/10.1093/ndt/gfh639

McCann B, Hunter R, McCann J (2002) Cocaine/heroin induced rhabdomyolysis and ventricular fibrillation. Emerg Med J 19(3):264. https://doi.org/10.1136/emj.19.3.264

Medina PJ, Sipols JM, George JN (2001) Drug-associated thrombotic thrombocytopenic purpura-hemolytic uremic syndrome. Curr Opin Hematol 8(5):286-293

Mihajlovic M, Fedecostante M, Oost MJ et al (2017) Role of vitamin $\mathrm{D}$ in maintaining renal epithelial barrier function in uremic conditions. Int J Mol Sci 18(12):2531. https://doi.org/10.3390/ ijms 18122531

Mihajlovic M, Hariri S, Westphal KCG et al (2019) Safety evaluation of conditionally immortalized cells for renal replacement therapy. Oncotarget 10(51):5332-5348. https://doi.org/10.18632 /oncotarget. 27152

Miller RP, Tadagavadi RK, Ramesh G, Reeves WB (2010) Mechanisms of Cisplatin nephrotoxicity. Toxins (Basel) 2(11):24902518. https://doi.org/10.3390/toxins2112490

Morizane R, Lam AQ, Freedman BS, Kishi S, Valerius MT, Bonventre JV (2015) Nephron organoids derived from human pluripotent stem cells model kidney development and injury. Nat Biotechnol 33:1193. https://doi.org/10.1038/nbt.3392

Murphy RA, Stafford RM, Petrasovits BA, Boone MA, Valentovic MA (2017) Establishment of HK-2 cells as a relevant model to study tenofovir-induced cytotoxicity. Int J Mol Sci. https:// doi.org/10.3390/ijms18030531

Naughton CA (2008a) Drug-induced nephrotoxicity. Am Fam Physician 78(6):743-750

Naughton CA (2008b) Drug-induced nephrotoxicity. Am Fam Physician 78:743-750

Navis G, Faber HJ, de Zeeuw D, de Jong PE (1996) ACE inhibitors and the kidney. Drug Saf 15:200-211. https://doi. org/10.2165/00002018-199615030-00005

Nieskens TTG, Peters JGP, Schreurs MJ et al (2016) A human renal proximal tubule cell line with stable organic anion transporter 1 and 3 expression predictive for antiviral-induced toxicity. AAPS J 18:465-475. https://doi.org/10.1208/s1224 8-016-9871-8

Nigam SK (2018) The SLC22 transporter family: a paradigm for the impact of drug transporters on metabolic pathways, signaling, and disease. Annu Rev Pharmacol Toxicol 58(1):663-687. https://doi.org/10.1146/annurev-pharmtox-010617-052713

Nigam SK, Wu W, Bush KT, Hoenig MP, Blantz RC, Bhatnagar V (2015) Handling of drugs, metabolites, and uremic toxins by kidney proximal tubule drug transporters. Clin J Am Soc Nephrol 10(11):2039-2049. https://doi.org/10.2215/cjn.02440314

Nissim I, Horyn O, Daikhin Y et al (2006) Ifosfamide-induced nephrotoxicity: mechanism and prevention. Can Res 66(15):7824-7831. https://doi.org/10.1158/0008-5472. Can-06-1043

Ohana YH, Liron T, Prutchi-Sagiv S, Mittelman M, Souroujon MC, Neumann D (2013) Erythropoietin. In: Handbook of biologically active peptides, pp 1619-1626. https://doi.org/10.1016/b978-0$12-385095-9.00221-9$ 
Olyaei AJ, de Mattos AM, Bennett WM (2001) Nephrotoxicity of immunosuppressive drugs: new insight and preventive strategies. Curr Opin Crit Care 7(6):384-389

Onopiuk A, Tokarzewicz A, Gorodkiewicz E (2015) Cystatin C: a kidney function biomarker. Adv Clin Chem 68:57-69. https://doi. org/10.1016/bs.acc.2014.11.007

Ozer JS, Dieterle F, Troth S et al (2010) A panel of urinary biomarkers to monitor reversibility of renal injury and a serum marker with improved potential to assess renal function. Nat Biotechnol 28(5):486-494. https://doi.org/10.1038/nbt.1627

Pahl MV, Vaziri ND, Yuan J, Adler SG (2010) Upregulation of monocyte/macrophage HGFIN (Gpnmb/Osteoactivin) expression in end-stage renal disease. Clin J Am Soc Nephrol CJASN 5(1):5661. https://doi.org/10.2215/cjn.03390509

Palmer BF (2002) Renal dysfunction complicating the treatment of hypertension. N Engl J Med 347(16):1256-1261. https://doi. org/10.1056/NEJMra020676

Patzer L (2008) Nephrotoxicity as a cause of acute kidney injury in children. Pediatr Nephrol 23(12):2159-2173. https://doi. org/10.1007/s00467-007-0721-x

Pazhayattil GS, Shirali AC (2014) Drug-induced impairment of renal function. Int J Nephrol Renovasc Dis 7:457-468. https://doi. org/10.2147/IJNRD.S39747

Perazella MA (2005) Drug-induced nephropathy: an update. Expert Opin Drug Saf 4(4):689-706. https://doi.org/10.1517/14740 338.4.4.689

Petros WP, Hopkins PJ, Spruill S et al (2005) Associations between drug metabolism genotype, chemotherapy pharmacokinetics, and overall survival in patients with breast cancer. J Clin Oncol Off J Am Soc Clin Oncol 23(25):6117-6125. https://doi.org/10.1200/ jco.2005.06.075

Pianta TJ, Peake PW, Pickering JW, Kelleher M, Buckley NA, Endre ZH (2015) Clusterin in kidney transplantation: novel biomarkers versus serum creatinine for early prediction of delayed graft function. Transplantation 99(1):171-179. https://doi.org/10.1097/ tp.0000000000000256

Piazzon N, Bernet F, Guihard L et al (2015) Urine Fetuin-A is a biomarker of autosomal dominant polycystic kidney disease progression. J Transl Med 13:103. https://doi.org/10.1186/s1296 7-015-0463-7

Price SA, Davies D, Rowlinson R et al (2010) Characterization of renal papillary antigen 1 (RPA-1), a biomarker of renal papillary necrosis. Toxicol Pathol 38(3):346-358. https://doi. org/10.1177/0192623310362246

Raghavan V, Weisz OA (2016) Discerning the role of mechanosensors in regulating proximal tubule function. Am J Physiol Renal Physiol 310(1):F1-F5. https://doi.org/10.1152/ajprenal.00373.2015

Reeves WB, Kwon O, Ramesh G (2008) Netrin-1 and kidney injury. I. Netrin-1 is an early biomarker of acute kidney injury. Am J Physiol Renal Physiol 294(4):F731-F738. https://doi.org/10.1152/ ajprenal.00507.2007

Rodriguez-Barbero A, L’Azou B, Cambar J, Löpezlöpez-Novoa JM (2000) Potential use of isolated glomeruli and cultured mesangial cells as in vitro models to assess nephrotoxicity. Cell Biol Toxicol 16:145-153

Ronco C, Cicoira M, McCullough PA (2012) Cardiorenal syndrome type 1: pathophysiological crosstalk leading to combined heart and kidney dysfunction in the setting of acutely decompensated heart failure. J Am Coll Cardiol 60:1031-1042. https://doi. org/10.1016/J.JACC.2012.01.077

Rossert J (2001) Drug-induced acute interstitial nephritis. Kidney Int 60(2):804-817. https://doi.org/10.1046/j.1523-1755.2001.06000 2804.x

Rostami-Hodjegan A (2012) Physiologically based pharmacokinetics joined with in vitro-in vivo extrapolation of ADME: a marriage under the arch of systems pharmacology. Clin Pharmacol Ther 92(1):50-61. https://doi.org/10.1038/clpt.2012.65

Ryan MJ, Johnson G, Kiiu J, Fuerstenberg SM, Zager RA, Torok-Storb B (1994) HK-2: an immortalized proximal tubule epithelial cell line from normal adult human kidney. Kidney Int 45:48-57

Sakairi T, Abe Y, Kajiyama $\mathrm{H}$ et al (2010) Conditionally immortalized human podocyte cell lines established from urine. Am J Physiol Renal Physiol 298:F557. https://doi.org/10.1152/AJPRE NAL.00509.2009

Sakolish C, Weber EJ, Kelly EJ et al (2018) technology transfer of the microphysiological systems: a case study of the human proximal tubule tissue chip. Sci Rep 8(1):14882. https://doi.org/10.1038/ s41598-018-33099-2

Sampathkumar K, Rajiv A, Sampathkumar D (2016) Analgesic nephropathy - a painful progression. Clin Med Insights Urol. https://doi.org/10.4137/cmu.s13179

Sawai K, Mukoyama M, Mori K et al (2007) Expression of CCN1 (CYR61) in developing, normal, and diseased human kidney. Am J Physiol Renal Physiol 293(4):F1363-F1372. https://doi. org/10.1152/ajprenal.00205.2007

Schafer JA, Watkins ML, Li L, Herter P, Haxelmans S, Schlatter E (1997) A simplified method for isolation of large numbers of defined nephron segments. Am J Physiol Renal Physiol 273(4):F650-F657. https://doi.org/10.1152/ajpre nal.1997.273.4.f650

Schmouder RL, Strieter RM, Wiggins RC, Chensue SW, Kunkel SL (1992) In vitro and in vivo interleukin-8 production in human renal cortical epithelia. Kidney Int 41:98

Schutgens F, Rookmaaker MB, Margaritis T et al (2019) Tubuloids derived from human adult kidney and urine for personalized disease modeling. Nat Biotechnol 37:303-313. https://doi. org/10.1038/s41587-019-0048-8

Secker PF, Luks L, Schlichenmaier N, Dietrich DR (2017) RPTEC/ TERT 1 cells form highly differentiated tubules when cultured in a 3D matrix (1868-596X (Print))

Secker PF, Schlichenmaier N, Beilmann M, Deschl U, Dietrich DR (2019) Functional transepithelial transport measurements to detect nephrotoxicity in vitro using the RPTEC/TERT1 cell line. Arch Toxicol. https://doi.org/10.1007/s00204-019-02469 $-8$

Shimamoto K, Iimura O (1989) Physiological role of renal kallikreinkinin system in human. Adv Exp Med Biol 247A:87-96

Simon-Friedt BR, Wilson MJ, Blake DA, Yu H, Eriksson Y, Wickliffe JK (2015) The RPTEC/TERT1 cell line as an improved tool for in vitro nephrotoxicity assessments. Biol Trace Elem Res 166:66-71. https://doi.org/10.1007/s12011-015-0339-y

Sjögren A-K, Breitholtz K, Ahlberg E et al (2018) A novel multi-parametric high content screening assay in ciPTEC-OAT1 to predict drug-induced nephrotoxicity during drug discovery. Arch Toxicol 92:3175-3190. https://doi.org/10.1007/s00204-018-2284-y

Stray KM, Bam RA, Birkus G et al (2013) Evaluation of the effect of cobicistat on the in vitro renal transport and cytotoxicity potential of tenofovir. Antimicrob Agents Chemother 57(10):4982. https ://doi.org/10.1128/AAC.00712-13

Takasato M, Er PX, Becroft M et al (2014) Directing human embryonic stem cell differentiation towards a renal lineage generates a self-organizing kidney. Nat Cell Biol 16:118-126. https://doi. org/10.1038/ncb2894

Takasato M, Er PX, Chiu HS et al (2015) Kidney organoids from human iPS cells contain multiple lineages and model human nephrogenesis. Nature 526:564-568. https://doi.org/10.1038/ nature 15695

Troth SP, Simutis F, Friedman GS, Todd S, Sistare FD (2019) Kidney SAFETY ASSESSMENT: CURRENT PRACTICES IN DRUG DEVELOPMENT. Semin Nephrol 39(2):120-131. https://doi. org/10.1016/j.semnephrol.2018.12.002 
Uehara T, Yamate J, Torii M, Maruyama T (2011) Comparative nephrotoxicity of Cisplatin and nedaplatin: mechanisms and histopathological characteristics. J Toxicol Pathol 24(2):87-94. https://doi.org/10.1293/tox.24.87

Uetake R, Sakurai T, Kamiyoshi A et al (2014) AdrenomedullinRAMP2 system suppresses ER stress-induced tubule cell death and is involved in kidney protection. PLoS One 9(2):e87667. https://doi.org/10.1371/journal.pone.0087667

Vaidya VS, Ferguson MA, Bonventre JV (2008a) Biomarkers of acute kidney injury. Annu Rev Pharmacol Toxicol 48:463-493. https:// doi.org/10.1146/annurev.pharmtox.48.113006.094615

Vaidya VS, Waikar SS, Ferguson MA et al (2008b) Urinary biomarkers for sensitive and specific detection of acute kidney injury in humans. Clin Transl Sci 1(3):200-208. https://doi.org/10.111 1/j.1752-8062.2008.00053.x

van der Made TK, Fedecostante M, Scotcher D, et al. (2019) Quantitative translation of microfluidic transporter in vitro data to in vivo reveals impaired albumin-facilitated indoxyl sulfate secretion in chronic kidney disease. Mol Pharm. https://doi.org/10.1021/acs. molpharmaceut.9b00681

van Genderen AM, Jansen J, Cheng C, Vermonden T, Masereeuw R (2018) renal tubular- and vascular basement membranes and their mimicry in engineering vascularized kidney tubules. Adv Healthc Mater 7(19):e1800529. https://doi.org/10.1002/ adhm.201800529

Vervaet BA, D'Haese PC, Verhulst A (2017) Environmental toxininduced acute kidney injury. Clin Kidney J 10:747-758. https:// doi.org/10.1093/ckj/sfx062

Vlasakova K, Erdos Z, Troth SP et al (2014) Evaluation of the relative performance of 12 urinary biomarkers for renal safety across 22 rat sensitivity and specificity studies. Toxicol Sci Off J Soc Toxicol 138(1):3-20. https://doi.org/10.1093/toxsci/kft330

Vriend J, Nieskens TTG, Vormann MK et al (2018) screening of drug-transporter interactions in a $3 \mathrm{D}$ microfluidic renal proximal tubule on a chip. AAPS J 20:87. https://doi.org/10.1208/ s12248-018-0247-0

Walshe CM, Odejayi F, Ng S, Marsh B (2009) Urinary glutathione $\mathrm{S}$-transferase as an early marker for renal dysfunction in patients admitted to intensive care with sepsis. Crit Care Resusc J Australas Acad Crit Care Med 11(3):204-209

Wang JJ, Chi NH, Huang TM et al (2018) Urinary biomarkers predict advanced acute kidney injury after cardiovascular surgery. Crit Care (London, England) 22(1):108. https://doi.org/10.1186/ s13054-018-2035-8

Weber EJ, Chapron A, Chapron BD et al (2016) Development of a microphysiological model of human kidney proximal tubule function. Kidney Int 90(3):627-637. https://doi.org/10.1016/j. kint.2016.06.011

Weber EJ, Himmelfarb J, Kelly EJ (2017) Concise review: current and emerging biomarkers of nephrotoxicity. Curr Opin Toxicol 4:16-21. https://doi.org/10.1016/j.cotox.2017.03.002

Wei Z, Amponsah PK, Al-Shatti M, Nie Z, Bandyopadhyay BC (2012) Engineering of polarized tubular structures in a microfluidic device to study calcium phosphate stone formation. Lab Chip 12(20):4037-4040. https://doi.org/10.1039/c2lc40801e

Widemann BC, Adamson PC (2006) Understanding and managing methotrexate nephrotoxicity. Oncologist 11(6):694-703. https ://doi.org/10.1634/theoncologist.11-6-694

Wieser M, Stadler G, Jennings P et al (2008) hTERT alone immortalizes epithelial cells of renal proximal tubules without changing their functional characteristics. Am J Physiol Renal Physiol 295(5):F1365-F1375. https://doi.org/10.1152/ajprenal.90405.2008

Wilmer MJ, Saleem MA, Masereeuw R et al (2010) Novel conditionally immortalized human proximal tubule cell line expressing functional influx and efflux transporters. Cell Tissue Res 339:449-457. https://doi.org/10.1007/s00441-009-0882-y
Wilmer MJ, Ng CP, Lanz HL, Vulto P, Suter-Dick L, Masereeuw R (2016) Kidney-on-a-chip technology for drug-induced nephrotoxicity screening. Trends Biotechnol 34:156-170. https://doi. org/10.1016/j.tibtech.2015.11.001

Wilmes A, Bielow C, Ranninger C et al (2015) Mechanism of cisplatin proximal tubule toxicity revealed by integrating transcriptomics, proteomics, metabolomics and biokinetics. Toxicol In Vitro 30:117-127. https://doi.org/10.1016/J.TIV.2014.10.006

Wnorowski A, Yang H, Wu JC (2018) Progress, obstacles, and limitations in the use of stem cells in organ-on-a-chip models. Adv Drug Deliv Rev. https://doi.org/10.1016/j.addr.2018.06.001

Wu C-Y, Yang H-Y, Chien H-P, Tseng M-H, Huang J-L (2018) Urinary clusterin-a novel urinary biomarker associated with pediatric lupus renal histopathologic features and renal survival. Pediatr Nephrol 33(7):1189-1198. https://doi.org/10.1007/s0046 7-018-3924-4

Xia Y, Sancho-Martinez I, Nivet E, Rodriguez Esteban C, Campistol JM, Izpisua Belmonte JC (2014) The generation of kidney organoids by differentiation of human pluripotent cells to ureteric bud progenitor-like cells. Nat Protoc 9:2693-2704. https://doi. org/10.1038/nprot.2014.182

Xiao L, Liu Y-P, Xiao C-X, Ren J-L, Guleng B (2014) Serum TFF3 may be a pharamcodynamic marker of responses to chemotherapy in gastrointestinal cancers. BMC Clin Pathol 14:26. https:// doi.org/10.1186/1472-6890-14-26

Xie Y, Sakatsume M, Nishi S, Narita I, Arakawa M, Gejyo F (2001) Expression, roles, receptors, and regulation of osteopontin in the kidney. Kidney Int 60(5):1645-1657. https://doi.org/10.10 46/j.1523-1755.2001.00032.x

Xie HG, Wang SK, Cao CC, Harpur E (2013) Qualified kidney biomarkers and their potential significance in drug safety evaluation and prediction. Pharmacol Ther 137(1):100-107. https://doi. org/10.1016/j.pharmthera.2012.09.004

Yildiz C, Ozsurekci Y, Gucer S, Cengiz AB, Topaloglu R (2013) Acute kidney injury due to acyclovir. CEN Case Rep 2(1):38-40. https ://doi.org/10.1007/s13730-012-0035-0

Yin C, Wang N (2016) Kidney injury molecule-1 in kidney disease. Ren Fail 38(10):1567-1573. https://doi.org/10.1080/08860 $22 x .2016 .1193816$

Yu Y, Jin H, Holder D et al (2010) Urinary biomarkers trefoil factor 3 and albumin enable early detection of kidney tubular injury. Nat Biotechnol 28(5):470-477. https://doi.org/10.1038/nbt.1624

Yu S-M, Oh JM, Lee J et al (2018) Substrate curvature affects the shape, orientation, and polarization of renal epithelial cells. Acta Biomater 77:311-321. https://doi.org/10.1016/j.actbi o.2018.07.019

Zajjari Y, Azizi M, Sbitti Y, El Kabbaj D (2017) Nephrotoxicity in a patient treated with pemetrexed. Indian J Nephrol 27(3):243-244. https://doi.org/10.4103/0971-4065.202403

Zazuli Z, Otten LS, Drögemöller BI et al (2019) Outcome definition influences the relationship between genetic polymorphisms of ERCC1, ERCC2, SLC22A2 and cisplatin nephrotoxicity in adult testicular cancer patients. Genes (Basel) 10(5):364. https://doi. org/10.3390/genes10050364

Zhao P, Zhang L, Grillo J et al (2011) Applications of physiologically based pharmacokinetic (PBPK) modeling and simulation during regulatory review. Clin Pharmacol Ther 89(2):259-267. https:// doi.org/10.1038/clpt.2010.298

Zhao K-W, Murray EJB, Murray SS (2017) HK2 proximal tubule epithelial cells synthesize and secrete plasma proteins predominantly through the apical surface. J Cell Biochem 118:924-933. https://doi.org/10.1002/jcb.25786

Publisher's Note Springer Nature remains neutral with regard to jurisdictional claims in published maps and institutional affiliations. 